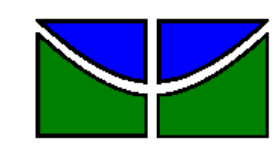

Universidade de Brasília

Faculdade de Economia, Administração e Contabilidade

Departamento de Administração

Curso de Graduação em Administração a distância

DESENVOLVIMENTO SUSTENTÁVEL E O CONSUMO CONSCIENTE:

Uma Análise do comportamento dos professores de ensino fundamentale médio das escolas particulares localizadas no bairro Jundiaí da cidade de Anápolis-GO

Brasília - DF 
Marly Alves de Oliveira

\title{
DESENVOL VIMENTO SUSTENTÁVEL E O CONSUMO CONSCIENTE: Uma Análise do comportamento dos professores de ensino fundamental e médio das escolas particulares localizadas no bairro Jundiaí da cidade de Anápolis-GO
}

\begin{abstract}
Monografia apresentada ao Departamento de Administração como requisito parcial à obtenção do título de Bacharel em Administração, na modalidade à distância, pela Universidade de Brasília (UnB).
\end{abstract}

Professor Supervisor: Dra. Selma Gonzales

Professor Tutor: Dra. Fabrícia Pimenta

Brasilia - DF 


\section{Oliveira, Marly Alves.}

Desenvolvimento Sustentável e o Consumo Consciente: Uma Análise do comportamento dos professores de ensino fundamental e médio das escolas particulares localizadas no bairro Jundiaí da cidade de Anápolis-GO / Marly Alves de Oliveira. - Brasilia, 2011.

$$
50 \mathrm{fl.:} \text { il. }
$$

Monografia Bacharel em Administração - Universidade de Brasília, Departamento de Administração - EaD, 2011.

Orientador: Prof ${ }^{a}$ Dra. Fabrícia Pimenta, Departamento de Administração.

1. Desenvolvimento Sustentável. 2. Responsabilidade Sócio Corporativa. 3. Consumo Consciente. 


\section{Um silêncio de três partes}

Noite outra vez. A pousada Marco do Percurso estava em silêncio, e era um silêncio em três partes.

A mais óbvia era uma quietude oca e repleta de ecos, feita das coisas que faltavam. Se houvesse vento, ele sussurraria por entre as árvores, faria a pousada ranger em suas juntas e sopraria o silêncio estrada afora, como folhas de outono arrastadas. Se houvesse uma multidão, ou pelo menos um punhado de homens na pousada, eles encheriam o silêncio de conversas e riso, do burburinho e do clamor esperados de uma casa em que se bebe nas horas sombrias da noite. Na verdade, não havia nenhuma dessas coisas e por isso o silêncio persistia.

Dentro da pousada, uma dupla de homens se encolhia num canto do bar. Os dois bebiam com serena determinação, evitando discussões sérias ou notícias inquietantes. Com isso, acrescentavam um silêncio pequeno e soturno ao maior e mais oco. Ele formava uma espécie de amálgama, um contraponto.

O terceiro silêncio não era fácil de notar. Se você passasse uma hora escutando, talvez começasse a senti-lo no assoalho de madeira sob os pés e nos barris toscos e lascados atrás do bar. Ele estava no peso da lareira de pedras negras, que conservava o calor de um fogo há muito extinto. Estava no lento vaivém de uma toalha de linho branco esfregada nos veios da madeira do bar. E estava nas mãos do homem ali postado, que polia um pedaço de mogno já reluzente à luz do lampião.

O homem tinha cabelos ruivos de verdade, vermelhos como a chama. Seus olhos eram escuros e distantes, e ele se movia com a segurança sutil de quem conhece muitas coisas.

Dele era a Pousada Marco do Percurso, como dele era também o terceiro silêncio. Era apropriado que assim fosse, pois esse era o maior silêncio dos três, englobando os outros dentro de si. Era profundo e amplo como o fim do outono. Pesado como um pedregulho alisado pelo rio. Era o som paciente - som de flor colhida - do homem que espera a morte.

Prólogo do livro O Nome Do Vento, de Patrick Rothfuss. 


\section{AGRADECIMENTOS}

Agradeço a Deus o dom da vida e a incrível capacidade de aprender.

Agradeço ao meu querido esposo e as minhas amadas filhas, por estarem sempre presentes, pelo apoio e compreensão que demonstraram durante esses anos de estudo.

Agradeço a Profa ${ }^{-}$Dra. Fabrícia Pimenta, minha orientadora, pela paciência, apoio e estímulo distribuídos tão generosamente; e a todos que de alguma forma contribuíram para a realização deste trabalho. 


\section{RESUMO}

O objetivo deste trabalho é analisar se os professores das escolas particulares de Anápolis adotam as práticas de consumidor consciente, tendo por base os critérios utilizados pelo Instituto Akatu no "Teste do Consumidor Consciente". O trabalho está dividido em duas partes, a primeira parte faz referência às ações ligadas ao desenvolvimento sustentável e à responsabilidade social corporativa de parte das organizações que atuam no Brasil. Esta análise foi realizada através de revisão bibliográfica. A segunda parte desta monografia faz uma abordagem sobre o consumo consciente e comportamento do consumidor. Para este fim, foi analisado o comportamento dos professores do ensino fundamental e médio, lotados em 05 escolas particulares localizadas no bairro Jundiaí, cidade de Anápolis-GO. Os dados foram coletados através de questionários aplicados junto a 97 professores, que constituem a amostra desta população. A pesquisa apontou que esses consumidores apresentam certo grau de preocupação com o meio ambiente e já consolidaram algumas das práticas de consumo consciente em sua rotina diária. Ao passo que outras ainda dependem de maior adesão por parte do público pesquisado. Entre essas práticas estão o hábito de conhecer e valorizar empresas que demonstram adotar ações sustentáveis e responsabilidade socioambiental, ler atentamente os rótulos dos produtos antes de decidir a compra e optar por produtos ambientalmente corretos, e cuidados com o manejo correto do lixo.

Palavras-chave: desenvolvimento sustentável, responsabilidade sócio corporativa e consumo consciente. 


\section{SUMÁRIO}

1. Introdução 06

$\begin{array}{ll}\text { 1.1. Formulação do problema } & 07\end{array}$

$\begin{array}{ll}\text { 1.2. Objetivo Geral } & 07\end{array}$

$\begin{array}{ll}\text { 1.3. Objetivos Específicos } & 07\end{array}$

$\begin{array}{ll}\text { 1.4. Justificativa } & 07\end{array}$

$\begin{array}{ll}\text { 2. Referencial Teórico } & 08\end{array}$

3. Métodos e Técnicas de Pesquisa 24

3.1. Tipo de descrição geral de pesquisa 24

3.2. População e amostra 24

$\begin{array}{ll}\text { 3.3. Instrumento de pesquisa } & 24\end{array}$

3.4. Procedimentos de coleta e de análise de dados 25

4. Resultados e Discussão 27

4.1. Análise dos resultados - Perfil do consumidor 27

4.2. Conhecendo o comportamento do consumidor consciente em 30 relação às compras

4.3. Conhecendo o comportamento do consumidor através das 36 suas práticas diárias relacionadas ao consumo consciente.

5. Considerações Finais 43

$\begin{array}{ll}\text { Referências } & 46\end{array}$

$\begin{array}{ll}\text { Apêndices } & 48\end{array}$ 


\section{INTRODUÇÃO}

O presente trabalho está dividido em duas partes. A primeira parte faz referência às ações ligadas ao desenvolvimento sustentável e a Responsabilidade Sócio Corporativa de parte das organizações que atuam no Brasil. Esta análise foi realizada por meio de uma revisão bibliográfica. Para este fim foram utilizados livros, periódicos, artigos científicos e sites do Instituto Ethos, Fundação Brasileira para o Desenvolvimento Sustentável-FBDS, Guia Exame de Sustentabilidade, e outras publicações especializadas no assunto.

A segunda parte desta monografia faz uma abordagem sobre o consumo consciente e comportamento do consumidor. Para esta pesquisa, em razão da otimização do tempo, optamos por analisar o comportamento dos educadores lotados nas escolas particulares localizadas no bairro Jundiaí, cidade de Anápolis$\mathrm{GO}$.

Este trabalho objetiva descobrir se esses consumidores incorporam em sua rotina diária algumas práticas de consumo consciente, e também perceber seu ponto de vista ou interesse sobre as empresas brasileiras que adotam ações que promovem o Desenvolvimento Sustentável e a Responsabilidade Social Corporativa. Para isso, foi realizada uma pesquisa de campo, utilizando um questionário estruturado, tendo como referência o modelo utilizado pelo Instituto Akatu no "Teste do Consumidor Consciente", disponibilizado no site desse Instituto.

O tema foi considerado oportuno, pois nas últimas décadas, o consumidor passou a ocupar uma posição importante que está diretamente relacionada ao assunto. De fato a participação do consumidor pode ser fundamental para fomentar o interesse e catalisar as mudanças de comportamento nas empresas e em sua cadeia de relacionamento, especialmente no que tange ao tema sustentabilidade e responsabilidade social corporativa.

Reconhecendo a abrangência deste tema, este estudo buscou ater-se ao conceito de responsabilidade socioambiental como o respeito ao meio ambiente, a transparência nos negócios, o respeito às leis e à sociedade onde a empresa está inserida. Já em relação ao desenvolvimento sustentável ou sustentabilidade pautouse no conceito da utilização dos recursos naturais de forma racional, com reflexo no combate ao desperdício, focado em como e quanto desses recursos são utilizados e de que forma eles são preservados. 


\subsection{Formulação do problema}

Considerando o propósito do presente trabalho, foi levantada a seguinte questão: Os educadores lotados nas escolas particulares de ensino fundamental e médio da cidade de Anápolis-GO incorporaram em sua rotina diária práticas relacionadas ao consumo consciente?

\subsection{Objetivo Geral}

O objetivo geral deste estudo é analisar se os professores das escolas particulares de Anápolis adotam as práticas de consumidor consciente, tendo por base os critérios utilizados pelo Instituto Akatu no "Teste do Consumidor Consciente".

\subsection{Objetivos Específicos}

A partir desse objetivo geral, pretende-se também:

- Traçar o perfil dos consumidores, objeto deste estudo;

- Identificar as ações que fazem parte do seu cotidiano como consumidor consciente.

- Conhecer o comportamento dos professores anapolinos, especificamente os do bairro Jundiaí, referente ao consumo consciente.

\subsection{Justificativa}

O processo de industrialização na forma em que foi se desenvolvendo ao longo do tempo, com sistemas produtivos que utilizam tecnologias poluentes, ineficiência energética, voraz exploração e desperdício de matéria prima e dos recursos naturais renováveis e não renováveis, assim como, o crescimento exponencial da população humana, e um sistema que estimula de forma excessiva o consumo de bens industrializados e naturais, tornaram-se questões relevantes no contexto do desenvolvimento da sociedade humana e da preservação ambiental. Pois estes fatores, fruto das ações dos seres humanos, conseguiram ultrapassar a 
capacidade que a terra tem de absorver a enorme quantidade de resíduos produzidos, bem como o potencial natural de recuperação do planeta.

Foi neste cenário que ocorreu a necessidade de despertar o senso de responsabilidade e interesse por parte do meio acadêmico, dos governantes, dos empresários, e enfim da sociedade em geral. A soma desse esforço coletivo resultou no incremento do diálogo entre os diversos atores e materializou-se ao longo dos anos em novos conhecimentos, tecnologias mais limpas, leis preservacionistas, trazendo para o cotidiano das pessoas os temas: Desenvolvimento Sustentável, Responsabilidade Social Corporativa e Consumo Consciente.

Considerando que o consumo sustentável está intimamente relacionado com a mudança de atitude e o poder que o consumidor pode exercer sobre as organizações, torna-se relevante este trabalho, que pretende abordar um segmento específico de consumidores verificando se já assimilaram o consumo consciente nos seus hábitos.

$\mathrm{O}$ ato de consumir está presente em todos os momentos e ser um consumidor consciente implica numa análise sobre nossos atos de consumo, bem como, estar ciente de que este ato terá efeito sobre o indivíduo/consumidor, sobre a economia, o ecossistema ou meio ambiente e sobre as relações sociais. Ao considerar que os educadores trabalham com a construção do conhecimento e também influenciam na formação de futuros consumidores torna-se importante conhecer suas práticas de consumo. 


\section{REFERENCIAL TEÓRICO}

O caminho trilhado pela humanidade no decorrer da história foi marcado pelo uso excessivo dos recursos naturais, como se estes fossem inesgotáveis. Esta visão, contudo, precisou ser revista. Atualmente é de conhecimento geral que o homem está degradando a natureza, seja para fazer frente as suas necessidades, por ganância ou por desconhecimento de que determinada atitude contribui para estragar o equilíbrio do ecossistema.

Neste trabalho a palavra ecossistema será utilizada conforme a definição clássica dada por Odum:

\footnotetext{
"Qualquer região natural que inclua organismos vivos e substâncias abióticas interatuando para promover uma troca de matéria entre as partes vivas e não vivas é um sistema ecológico ou ecossistema." (ODUM, apud ALMEIDA, 2009, p. 3)
}

A transformação começou incipiente nos anos 60 , quando emergiu entre outros movimentos, os relacionados ao ecossistema, ao meio ambiente ou ecológico. Ainda nesta década, esses movimentos foram se avolumando e alcançaram o campo político, criticando fortemente a forma de produção e o modo de vida daquela época. (GONÇALVES, 2004).

Um marco para o momento ambientalista foi o lançamento, em 1962, do livro Primavera Silenciosa ('Silent Spring'), da jornalista Rachel Carson. O livro causou grande impacto, dando início ao debate ambiental, não só nos países industrializados, mas conseguiu também envolver a comunidade internacional, gerando questionamentos sobre degradação ambiental, poluição, hábitos de consumo e bem estar social. (NASCIMENTO, 2008).

Outro documento que teve grande repercussão sobre a problemática ambiental e serviu para "despertar a consciência ecológica mundial" foi o relatório intitulado 'Os limites ao crescimento', estudo efetuado e publicado pelo Clube de Roma, fundado em 1968. Diversos estudiosos pesquisaram sobre o consumo e as reservas dos recursos naturais, expondo os limites da terra em suportar o desgaste proveniente do desenvolvimento econômico e do aumento acelerado da população. Esse texto colaborou ainda, para a realização da primeira conferência promovida pela Organização das Nações Unidas - ONU, em 1972, sobre Meio Ambiente e 
Desenvolvimento, que reuniu representantes dos países desenvolvidos, em torno da realidade mundial e do despertar da "sociedade para os limites da exploração do planeta". (NASCIMENTO, 2008, p. 18)

A partir desses documentos estava lançada a 'bandeira ambiental/ecológica, que conseguiu agregar governos, sociedade civil e a imprensa. Por toda parte eclodiam discussões sobre questões ambientais, o futuro da humanidade e de todo o ecossistema terrestre. Foi no final dos anos 70 que surgiram as Organizações Não Governamentais Internacionais como o Greenpeace e Amigos da Terra. Essas organizações responsabilizavam as empresas pela maioria dos problemas ambientais existentes. O movimento liderado por elas era furioso, passional, e implacável. Mobilizaram pessoas simpatizantes e fizeram inúmeras campanhas contra as companhias. Nos anos 70 e nas décadas seguintes as Organizações Não Governamentais conseguiram que as empresas mudassem ou abandonassem projetos que impactavam negativamente o meio ambiente. (BENNETT, 2010)

No final da década de 80 , outro documento nomeado como Relatório Brundtland, causou impacto mundial ao definir o conceito de desenvolvimento sustentável. Este conceito foi amplamente aceito e divulgado em 1987, pela Comissão Mundial sobre o Meio Ambiente - CMMA das Nações Unidas. (NASCIMENTO, 2008)

"[...] o desenvolvimento sustentável é um processo de transformação no qual a exploração dos recursos, a direção dos investimentos, a orientação do desenvolvimento tecnológico e a mudança institucional se harmonizam e reforçam o potencial presente e futuro [...] é aquele que atende às necessidades do presente sem comprometer a possibilidade de as gerações futuras atenderem às suas próprias necessidades (IBGE, 2002).

Desde então este conceito tem sido utilizado para avaliar/criticar/analisar o desenvolvimento nas dimensões econômica, social e ambiental. Além disso, foi utilizado como inspiração para a conscientização da sociedade, induzindo-a a questionar se as práticas econômicas e sociais adotadas até então estavam promovendo a "harmonia entre os seres humanos, [...] a humanidade e a natureza." (NASCIMENTO, 2008) 
Segundo Nascimento, ao interligar as questões ambientais e o desenvolvimento, o relatório "[...] faz um alerta para a necessidade de as nações unirem-se na busca de alternativas para os rumos vigentes do desenvolvimento, a fim de evitar a degradação em nível planetário." (2008, p. 19).

O Brasil, assim como muitos países em desenvolvimento, para alcançar "progresso" priorizou o desenvolvimento econômico sem nenhuma preocupação com as questões ambientais e/ou sociais. Com grande quantidade de terras agricultáveis e a abundância de recursos hídricos, estimulou o desmatamento de florestas naturais, onde foram criadas fronteiras agrícolas e formação de pastagens. Degradou diversos ecossistemas com extração de minérios, sendo que esse processo destrutivo ocorre há mais de 500 anos, isto é, desde a sua colonização. (BARBIERI, 2004).

As primeiras ações voltadas para as questões ambientais, no país, ocorreram nos últimos anos da década de 50, a União Protetora do Ambiente Natural - UPAN, foi fundada em 1955, em São Leopoldo - RS, pelo naturalista Henrique Roessler, e a Fundação Brasileira para a Conservação da Natureza FBCN, fundada em 1958, no Rio de Janeiro, por um grupo formado por cientistas, políticos e jornalistas. A FBCN inspirou-se nos movimentos ativistas de Londres, e atuou na preservação da fauna e da flora brasileira. (URBAN, 2001; JACOBI, 2003).

O movimento ecológico no Brasil dos anos 70 e 80 estava centrado em lideranças individuais. Suas ações centralizavam-se principalmente nas regiões sul e sudeste do país, com pouca repercussão regional ou nacional.

Naquela época os grupos ambientalistas brasileiros não se caracterizavam pelo ativismo, a atuação estava focada principalmente na biodiversidade, alertando sobre os atos que colocavam em risco de extinção animais e florestas.

Segundo dados do Cadastro Nacional de Instituições ambientais em 1973 havia apenas 12 grupos atuantes no país, onde a Associação Gaúcha de Proteção ao Ambiente Natural - AGAPAN se destacou ao adotar ações mais abrangentes questionando os impactos ambientais provocados pela poluição industrial e o uso de agrotóxico na atividade agrícola. (JACOBI, 2003).

Segundo Jacobi (2003) neste período não ocorreram grandes manifestações por parte dos movimentos ambientalistas, contudo o autor cita algumas campanhas específicas que tiveram impacto nacional e internacional. 
"[...] em alguns casos desenvolvem campanhas de abrangência regional e mesmo nacional, como é o caso da campanha de denúncia contra o desmatamento na Amazônia em 1978, a luta contra a inundação de Sete Quedas no Rio Paraná (1979-1983), a luta contra a construção de usinas nucleares (1977- 1985), a luta pela aprovação de leis do controle e de estímulo ao uso intensivo de agrotóxicos (1982-1985). Muitas destas lutas obtiveram bastante repercussão no exterior, e foram referência relevante para a multiplicação de pressões contra o governo brasileiro durante os anos finais do regime autoritário, sendo que a maioria das práticas eram pautadas pelo voluntarismo dos militantes mais engajados." (JACOBI, 2003) .

Uma das primeiras leis do ordenamento jurídico brasileiro que versou sobre as questões ambientais foi a Lei Federal 6.938/1981, que fixou a Política Nacional do Meio Ambiente, estabelecendo o seguinte no artigo $2^{\circ}$ :

"A Política Nacional do Meio Ambiente tem por objetivo a preservação melhoria e recuperação da qualidade ambiental propícia a vida, visando assegurar, no País, condições ao desenvolvimento sócio-econômico, aos interesses da segurança nacional e a proteção da dignidade da vida humana $[\ldots] "$

A Constituição Federal de 1988 confirmou as diretrizes políticas dessa lei em seu Título VIII, Capítulo VI, artigo 225, e esclareceu que é direito de todos usufruírem de um meio ambiente ecologicamente equilibrado.

\footnotetext{
"Todos têm direito ao meio ambiente ecologicamente equilibrado, bem de uso comum do povo e essencial à sadia qualidade de vida, impondose ao Poder Público e à coletividade o dever de defendê-lo e preservá-lo para as presentes e futuras gerações". (CF - 1988).
}

No ano de 1992 o Brasil sediou a Conferência das Nações Unidas sobre Meio Ambiente e Desenvolvimento, também conhecida como RIO-92. Foi durante este evento que as lideranças de mais de 178 países aprovaram a Agenda 21. Esta agenda é um norteador importante do ponto vista do desenvolvimento sustentável, que deve ser observado pelos países signatários.

Para Nascimento (2008), a Agenda 21 Global, enumerou de forma clara alguns objetivos, listados a seguir, que os países participantes da RIO-92 assumiram o compromisso de seguir quando assinaram o referido documento:

$\checkmark$ preservar as florestas e as nascentes; 
$\checkmark$ buscar novas opções para substituir os gases responsáveis pela destruição da camada de ozônio; entre os mais conhecidos estão os CFCs - usualmente utilizados em refrigeradores, sprays, ares-condicionados e equipamentos industriais;

$\checkmark$ proibir a pesca destrutiva;

$\checkmark$ pesquisar novas fontes de energia renovável;

$\checkmark$ reduzir a quantidade de lixo produzido; e

$\checkmark$ encontrar combustíveis alternativos, menos poluentes.

Corroborando com o tema, Barbieri referiu-se a Agenda 21 como um "plano de intenção", afirmando que a execução das ações inerentes aos objetivos do documento depende do interesse dos políticos e de "mobilização da sociedade".

"[...] a Agenda 21 é uma espécie de manual para orientar as nações e as suas comunidades nos seus processos de transição para uma nova concepção de sociedade. Ela não é um tratado ou uma convenção capaz de impor vínculos obrigatórios aos estados signatários, na realidade é um plano de intenções não mandatório cuja implementação depende da vontade política dos governantes e da mobilização da sociedade." (BARBIERI, 2005, P.65)

Assim, a Agenda 21 brasileira foi criada em 1997 e inovou no sentido de ampliar as ações foco da agenda. O pioneirismo brasileiro foi assim descrito por Nascimento:

"[...] o objetivo comum a ser atingido não está restrito à preservação do meio ambiente, mas ao desenvolvimento sustentável ampliado e progressivo que introduz na discussão a busca do equilíbrio entre crescimento econômico, equidade social e preservação ambiental". (2008, p.40).

O Brasil adotou também, o sistema de agendas locais, onde governo e sociedade civil de cada cidade e comunidade cooperam para criar sua agenda voltada para sua realidade sem, contudo desperceber os seguintes objetivos gerais: (NASCIMENTO, 2008).

- demonstrar respeito às diferenças culturais e comunidades;

- primar pela integração; 
- buscar participação e cidadania;

- almejar a melhoria do padrão de vida das comunidades;

- buscar a redução das desigualdades sociais; e

- mudança de mentalidades.

Os anos 70 e 80 podem ser chamados de período legislativo. Os governos em todo o mundo estavam criando leis ambientais com o propósito de limitar a ação agressiva por parte do processo industrial. Neste período a adesão do mundo corporativo às questões ambientais limitava-se ao cumprimento da lei. Nos últimos 20 anos ocorreram mudanças na forma de ver as questões ambientais. As organizações passaram a aperfeiçoar o processo produtivo, a meta era a redução dos danos causados ao meio ambiente. Neste período surgiram as tecnologias mais limpas, isto é, modelos de produção menos poluentes, e o conceito de "ciclo de vida" do produto, que nada mais é do que tornar o produto ambientalmente correto desde o seu nascimento até o descarte ou reutilização do mesmo. (NASCIMENTO, 2008).

No Brasil, esse movimento de tomada de consciência das empresas sobre o seu papel nas dimensões ambiental e social foi impulsionado pela Conferência das Nações Unidas para o Meio Ambiente e Desenvolvimento - Rio-92, realizada na cidade do Rio de Janeiro, naquele mesmo ano. Na esteira da conferência foram criadas importantes organizações como o Instituto Ethos de Empresas e Responsabilidade Social, o Conselho Empresarial Brasileiro para o Desenvolvimento Sustentável - CEBDS e Fundação Brasileira para o Desenvolvimento Sustentável FBDS, que tinham como objetivo auxiliar as empresas brasileiras na discussão e aplicação do conceito de desenvolvimento sustentável. (INSTITUTO ETHOS, CEBDS, FBDS).

Deste contexto histórico nota-se uma alternância entre os papéis de cada ator. Os movimentos ambientalistas pressionaram, o poder público e organismos internacionais tomaram medidas corretivas e preventivas ao instituir leis, normas ou princípios que devem ser observados por todas as organizações e por todo cidadão coletiva ou individualmente.

O desenvolvimento econômico, a globalização e o progresso tecnológico tornaram o mundo menor. A comunicação pode ser feita em tempo real ao redor do mundo, os meios de transporte reduzem as distâncias, as empresas globais rompem fronteiras ultrapassando as barreiras culturais, econômicas e linguísticas. Foi neste cenário que o mundo percebeu que o que ocorre em qualquer parte do planeta tem 
efeitos sobre todos. Desse modo, fenômenos como o buraco na camada de ozônio, aquecimento global, chuva ácida e o efeito estufa causam impacto global, pois não afetam apenas as localidades onde foram gerados, sendo suas consequências danosas sentidas por todos em qualquer parte do planeta.

Numa tentativa de solucionar ou amenizar esses impactos ambientais muitos cientista viram a necessidade de aumentar/incrementar as pesquisas na busca de alternativas viáveis para conciliar desenvolvimento econômico e progresso com a capacidade de sustentação do ecossistema, a sobrevivência da humanidade e a preservação do planeta para gerações futuras.

E é neste contexto que há aproximadamente 50 anos vem se construindo o conceito de Responsabilidade Social Corporativa.

Mas, segundo Oliveira (2008), ainda não existe uma definição clara sobre o tema responsabilidade social, embora tenha crescido muito o número de matérias sobre o assunto nos últimos anos. Para este autor,

\begin{abstract}
"O interesse em Responsabilidade Social de Empresas (SER), ou os termos similares Responsabilidade Social Corporativa (RSC) e Cidadania Corporativa (CC) vem aumentando significativamente nos últimos anos no Brasil e no mundo. Muitas empresas estão ávidas para atuar e mostrar o quanto são socialmente responsáveis. Na mídia e academia tem crescido o número de reportagens, artigos e livros sobre o tema [...]. Entretanto possivelmente devido à novidade do conceito, ainda existem muitos debates sobre o que exatamente é responsabilidade social de empresas, como surgiu e como se aplica esse conceito." (2008, p. 65)
\end{abstract}

Dadas às particularidades do tema optou-se por utilizar neste trabalho o conceito definido e divulgado pelo WBCSD, em 1998:

"Responsabilidade Social Corporativa (RSC) é o comprometimento contínuo pelo negócio, de se comportar eticamente e de contribuir para o desenvolvimento econômico, enquanto melhora a qualidade de vida de sua força de trabalho e de suas famílias, assim como da comunidade local e da sociedade como um todo." 
Para Almeida (2009), o conceito indica uma mudança de comportamento contínua e duradoura por parte do empresariado que deve ser traduzida em ações que beneficiem todos os envolvidos.

"[...] prega o comprometimento permanente dos empresários com a adoção de um comportamento ético e um desenvolvimento econômico que contemple a melhoria da qualidade de vida de empregados e suas famílias, das comunidades nas quais as empresas operam e da sociedade como um todo. Os valores embutidos na noção de Responsabilidade Social Corporativa (RSC) são o respeito aos direitos do bem-estar das comunidades e do progresso social." (2009, p. 49).

Embora ainda existam casos em que os esforços em prol da RSC sejam apenas "de fachada", as empresas devem lembrar que, dadas as circunstâncias dos avanços tecnológicos, principalmente nos meios de comunicação, o mundo vive conectado, assim "todos sabem tudo sobre todos em tempo real. Não há como escamotear um passivo ambiental ou social." (2009, p.113).

Deste modo, Almeida admoesta que para assegurar desenvolvimento duradouro, ou a sustentabilidade do negócio, os empresários não devem perder o foco, mas assegurar que todos na empresa busquem:

> visão ampla dos desdobramentos ambientais, sociais e econômicos dos atuais padrões de crescimento;

$>$ perspectivas de longo prazo relativas aos interesses e direitos das gerações atuais e futuras; $\mathrm{e}$

$>$ ações inclusivas que considerem a necessidade de as pessoas estarem envolvidas nas decisões que afetam suas vidas, como condições básicas de cidadania.

Semelhante à definição de RSC, apesar da falta de consenso sobre o assunto, a revisão bibliográfica mostrou que é possível afirmar que a sustentabilidade corporativa não necessariamente significa redução nos lucros financeiros, aumentos dos custos, e processos penosos e burocráticos. Em muitos casos a mudança de foco na gestão empresarial tem trazido resultados surpreendentemente favoráveis. 
Portanto parece que o grande desafio das organizações consiste em aliar o objetivo tradicional - que é o melhor retorno financeiro ou lucro - com a preservação ambiental e a justiça social. (ALMEIDA, 2009).

Assim, torna-se relevante entender que o papel da organização como incubadora de mudanças relacionadas ao desenvolvimento sustentável não está apenas no poder financeiro, mas também na capacidade de atravessar as fronteiras e compartilhar conhecimentos, tecnologias, e miscigenar culturas. Para Élisabeth Laville "[...] a empresa tem hoje o poder de fazer as coisas mudarem bem mais rapidamente do que as regulamentações, e de maneira bem mais eficiente do que as políticas". (2009, p.40). Fazendo uma abordagem do poder econômico financeiro das grandes corporações a autora corrobora seu entendimento citando uma análise sobre comércio justo do Full Voice e faz referência também ao livro do escritor Stuart L. Hart.

\footnotetext{
"Algumas empresas multinacionais pesam hoje mais do que vários Estados juntos [...] em 1995, a americana Wall-Mart era mais rica do que Israel, Polônia e Grécia - e ocupava apenas a décima-segunda posição entre as empresas mais poderosas do mundo. Em 2004, as vendas das dez maiores multinacionais ultrapassavam os PIBs conjuntos dos cem países mais pobres". ${ }^{1}$
}

Nos últimos 15 anos muitas empresas globais e nacionais encontraram soluções inovadoras para as questões socioambientais, sendo possível afirmar que estas empresas estão enfrentando com sucesso o desafio de reinventar-se na busca do desenvolvimento sustentável. Este desenvolvimento acontece quando as organizações incluem nas estratégias empresariais de médio e longo prazo o interesse e o cuidado com o social e ambiental, além do econômico financeiro.

Assim a sustentabilidade corporativa, apesar dos custos de implantação, tem a longo prazo, contribuído para o crescimento e longevidade das empresas ao criar oportunidades de rentabilizar e expandir os negócios. (Instituto Ethos, WBCSD, FBDS, Guia EXAME de Sustentabilidade).

\footnotetext{
1- Full Voice, especial sobre comércio justo, The Body Shop, 2000 e livro de Stuart L. Hart. Capitalism at the Crossroads. Filadélfia/NY, Wharton School Publishing/Pearson Education. 2005, apud LAVILLE, 2009 p 41.
} 
Em 2008, o Instituto Ethos em parceria com o Instituto Akatu desenvolveu pesquisas junto ao empresariado brasileiro, com o objetivo de mapear as ações efetivas de RSC e sustentabilidade corporativa. A proposta do estudo foi avaliar junto às empresas brasileiras "[...] o que elas já têm feito de fato, com base nas próprias declarações das empresas sobre suas práticas". (AKATU, 2008)

Desta pesquisa foi possível verificar que as empresas ainda têm um longo caminho a percorrer; mas nas comparações efetuadas com a pesquisa de 2004 ficou evidente que o mundo corporativo ampliou a abrangência das ações sustentáveis, segundo informou o Instituto Ethos, "[...] o aumento de 11 para 22 práticas nestes quatro anos indica a intensificação do envolvimento das empresas com a RSE" - Responsabilidade Social Empresarial. (ETHOS, AKATU).

Neste contexto, evidencia-se que muitas empresas nacionais, estão adotando as mesmas ações que muitas organizações em todo o mundo, isto é, incorporaram os aspectos relacionados à RSC e ao Desenvolvimento Sustentável ações buscando o bem-estar social e cuidados com o meio ambiente - na sua definição estratégica, na operação do negócio e nas relações com stakeholders, termo utilizado para identificar aqueles que estão envolvidos direta ou indiretamente com as atividades da empresa.

Conforme descreve Almeida (2009), o autor do conceito de "stakeholders" Edward Freeman nos assegura que o público interessado, sejam grupos ou indivíduos, não deve ser relegado a segundo plano, mas sim

\footnotetext{
"[...] considerado como um elemento essencial na planificação estratégica de negócios. A tradução mais usual e aceita desse termo é "parte interessada". Entende-se, portanto, que esse conceito se refere a qualquer pessoa ou entidade afetada pelas atividades de uma organização, como: empregados, acionistas, governos, sindicatos, organizações civis e/ou governamentais, dentre outras." (2009, p. 130).
}

O Guia EXAME de Sustentabilidade é um periódico que anualmente premia empresas que se destacam na aplicação de práticas sustentáveis e RSC. Seu conteúdo apresenta de forma clara e sucinta o perfil das organizações e suas principais ações sustentáveis, neste aspecto, pode ser considerado como uma 
interessante fonte de pesquisa sobre a atuação do universo corporativo brasileiro. Segundo Cláudia Vassalo, diretora de redação do Guia EXAME， ano 2010, as práticas sustentáveis são desafiadoras e envolvem ações estruturantes tais como:

\footnotetext{
"[...] eliminação de rincões de miséria, pela universalização do saneamento básico, pelo investimento consistente em pesquisa e desenvolvimento, pela valorização da inovação tecnológica e, sobretudo pela garantia de uma educação de qualidade para todos os brasileiros. (VASSALO, apud GUIA EXAME DE SUSTENTABILIDADE, 2010).
}

Esta gigantesca missão não pode ser marginalizada por nenhum dos atores envolvidos no processo, ou seja, governos, mundo corporativo, centros acadêmicos e sociedade, de forma coletiva ou individual, todos devem estar engajados para alcançar, ou no mínimo diminuir o abismo entre o real e o desejável.

O mapeamento da atividade empresarial mostra que muitas empresas brasileiras estão comprometidas com o tema e desenvolvem projetos em parceria com ONGs, universidades, governos, sociedade civil e voluntários que envolvem as dimensões ambiental, social e econômico-financeira. Algumas questões importantes que estão relacionadas ao crescimento sustentável e que constam das estratégias corporativas destas empresas, avaliadas pelo Guia Exame de Sustentabilidade:

- gestão de recursos hídricos;

- controle da emissão de gases de efeito estufa;

- conservação da biodiversidade e ecossistemas terrestres;

- pesquisa de energia renovável e busca de eficiência energética;

- gestão de resíduos sólidos;

- investimentos em educação da comunidade onde atua;

- seleção e capacitação de parceiros locais;

- atuação transparente e combate à corrupção; e

- diversidade, inclusão e cuidados com saúde e segurança dos colaboradores.

A seguir trataremos de alguns casos de "empresas-modelo" pelos parâmetros do Guia Exame. O período de 2010 lista um total de 20 empresas como melhores exemplos de sustentabilidade e RSC. 


\section{EMPRESA-MODELO:}

CPFL Energia - investiu em energia renovável. Com a utilização de bagaço de cana-de-açúcar pôs em funcionamento a usina termoelétrica Baldin, com capacidade instalada para atender uma cidade de 200 mil habitantes. Este empreendimento foi resultado de uma parceria com a empresa Baldin, do setor sucroalcooleiro, responsável pelo fornecimento do bagaço de cana. A CPFL investiu 103,5 milhões de reais nesta fonte de energia renovável. O projeto inclui outras quatro usinas que devem entrar em funcionamento até 2012.

A empresa investe também em parques eólicos no nordeste brasileiro com investimento superior a 800 milhões de reais.

Wilson Ferreira Junior, presidente da companhia justifica a estratégia coorporativa da seguinte forma:

\footnotetext{
"O mundo caminha para modelos de produção de baixa emissão de carbono. A legislação ambiental gradualmente imporá metas de redução de emissões e restrições à produção com base em consumo fósseis. Temos de estar preparados"
}

A CPFL também criou programas para reduzir o desperdício. Entre as medidas adotas estão a substituição de 749 mil lâmpadas incandescentes por modelos mais econômicos para melhorar a eficiência energética. Para reduzir os impactos ambientais, em 2009, doou 310mil mudas de árvores a diversas cidades no país. (Guia Exame de Sustentabilidade 2010, FBDS).

Suzano Papel e Celulose - destaque em controle da emissão de gases de efeito estufa. Em 2003 a empresa iniciou o registro das suas emissões dentro da companhia. Em 2009 tornou-se a primeira no mundo a calcular a pegada de carbono, que é uma evolução do inventário em vigor desde 2003, visto que contabiliza as emissões em todo o ciclo de vida do produto - dos fornecedores até o cliente final. A companhia possui 256 mil hectares de área certificada por Forest Stewardship Council - FSC considerado o selo verde mais respeitado do mundo.

Diariamente a empresa planta 400mil árvores que implica em 7 milhões de toneladas de carbono sequestrado por ano. 
Embora atualmente o mercado de créditos de carbono só permita a comercialização do gás capturado por florestas naturais, a Suzano está se antecipando, se for liberada a comercialização da captura por florestas plantadas, suas ações serão duplamente recompensadas.

No ano passado a companhia investiu 31,3 milhões de reais em projetos de educação, meio ambiente e geração de renda. A fábrica de Mucuri-BA conseguiu produzir através da queima de resíduos da produção $95 \%$ da energia consumida. A empresa trabalha ainda com metas de redução de consumo de água nas suas unidades. (GUIA EXAME DE SUSTENTABILIDADE 2010, FBDS)

Após as considerações sobre o que o estado e as empresas estão fazendo, torna-se necessário retomar o tema agora do ponto de vista do consumidor, peça ou ator fundamental neste jogo de interesses.

Por definição consumidor é aquele que compra e/ou utiliza produtos oriundos do agronegócio, comércio, indústria, e serviços.

Considerado a razão de ser da empresa, e consequentemente da sociedade capitalista, já que se não existisse a "figura" do consumidor não haveria demanda por produtos e serviços, o seu comportamento tem sido objeto de pesquisas e estudo nas áreas de administração, marketing, sociologia, psicologia entre outras.

Segundo Samara e Morsch (2005), "ele é o centro e o foco de todo negócio e as empresas competem ferozmente para conquistar sua atenção e preferência [...]" (2005, p.3).

Assim, é oportuna uma análise sobre o poder de escolha do consumidor diante dos inúmeros produtos e serviços disponíveis no mercado, que disputam sua atenção e interesse, relacionando o ato de consumir ao desenvolvimento sustentável ou sustentabilidade.

Para o sociólogo Giddens (2005), as questões relacionadas ao desenvolvimento sustentável não podem ser consideradas à margem do comportamento do consumidor, já que existe uma correlação entre os temas.

\footnotetext{
"Grande parte do debate em torno do meio ambiente e do desenvolvimento econômico depende dos padrões de consumo.

O consumo refere-se às mercadorias, aos serviços, à energia e aos recursos que são esgotados pelas pessoas, instituições e sociedades. Esse é um fenômeno que apresenta tanto dimensões positivas quanto negativas. [...] $\mathrm{O}$ consumo está associado ao desenvolvimento
} 
econômico - com a elevação dos padrões de vida, as pessoas têm mais condições de arcar com comida, roupas, itens pessoais, tempo de lazer, férias carros e assim por diante. [...] Os padrões de consumo não estão apenas esgotando os elementos naturais existentes, como também estão contribuindo para sua degradação através dos resíduos e das emissões de substâncias nocivas." (2005, p. 487).

Similar ao que ocorreu com a RSC e o desenvolvimento sustentável, o conceito de consumo sustentável ainda está sendo consolidado. Na esteira dos movimentos ecológicos das décadas de 70 e 80 , levantaram-se vozes mostrando a necessidade de envolver e sensibilizar os consumidores a respeito destas questões vitais. Esta conscientização dos consumidores fez surgir a ideia do consumo sustentável e tornou evidente para ele - consumidor - o grande poder encerrado no ato de comprar/consumir.

Conforme definido pelo Programa das Nações Unidas para o Desenvolvimento - PNUD (1998):

"O consumo sustentável significa o fornecimento de serviços e de produtos correlatos, que preencham as necessidades básicas e dêem uma melhor qualidade de vida, ao mesmo tempo em que se diminui o uso de recursos naturais e de substâncias tóxicas, assim como as emissões de resíduos e de poluentes durante o ciclo de vida do serviço ou do produto, com a idéia de não se ameaçar as necessidades das gerações futuras".

Fazendo coro com os demais estudiosos do tema, Barbiere menciona que a Educação Ambiental pode ser utilizada como um indutor de mudanças junto ao consumidor.

\footnotetext{
"A educação ambiental deve estimular as pessoas a serem portadoras de soluções e não apenas de denúncias [...] Devem também produzir mudanças nas suas próprias condutas, modificando, por exemplo, seus hábitos de consumo." (2004, p.77).
}

Assim sendo, o consumo sustentável, está intimamente relacionado com a mudança de atitude não só do estado, do mundo corporativo, mas também dos consumidores e da sociedade em geral.

Nesta mesma linha de raciocínio Tachizawa (2009) afirma que: 
"[...] o consumidor do futuro, inclusive no Brasil, passará a privilegiar não apenas preço e qualidade, mas principalmente, o comportamento social das empresas fabricantes desses produtos. (...) O cliente continuará a penetrar cada vez mais na empresa, numa escalada progressiva, na qual a solicitação do cliente sinalizará as decisões do executivo da empresa". (2009, p.5).

Ainda segundo o autor a nova postura do consumidor impõe o seguinte desafio:

\begin{abstract}
"Um dos maiores desafios que o mundo enfrenta neste novo milênio é fazer com que as forças de mercado protejam e melhorem a qualidade do ambiente, com a ajuda de padrões baseados no desempenho e uso criterioso de instrumentos econômicos, num quadro harmonioso de regulamentação. O novo contexto econômico caracteriza-se por uma rígida postura dos clientes, voltada à expectativa de interagir com organizações que sejam éticas, com boa imagem institucional no mercado, e que atuem de forma ecologicamente responsável." (2009, p. 5).
\end{abstract}

Segundo esta linha de raciocínio, é possível afirmar que a Responsabilidade Social Corporativa e ações voltadas para o Desenvolvimento Sustentável influenciam positivamente as crenças e atitudes das pessoas, dessa forma, o consumidor pode escolher ou recusar os produtos, dependendo das ações das empresas. Dados confirmados pela pesquisa conduzida pelo Instituto Ethos em parceria com o Instituto Akatu em 2004 e 2010. Essas pesquisas mostraram que o consumidor brasileiro está mais consciente e demonstra preferência para adquirir produtos de empresas que investem em RSC e Sustentabilidade.

Desse modo, no decorrer dos anos o consumidor aprendeu a ir além das exigências por preços e produtos/serviços de qualidade. Atualmente os temas relacionados à preservação do planeta e integridade humana fazem parte do seu cotidiano.

Este consumidor passou a ser conhecido como consumidor cidadão, ou consumidor consciente. Samara e Morsch (2005) o descreve como: "[...] politizado, bem informado e ético. Posiciona-se e participa ativamente sobre questões que the afetam, luta por seus direitos e exige das empresas e organizações o devido cumprimento de seu papel na sociedade." (2005, p. 244). 


\section{MÉTODOS E TÉCNICAS DE PESQUISA}

\subsection{Tipo e descrição geral da pesquisa}

Trata-se de uma pesquisa de caráter exploratório, com uma abordagem descritiva e quantitativa. Depois de recolhidos os questionários, iniciamos a contagem das informações; primeiro dos dados pessoais que ajudaram a traçar o perfil do consumidor, depois as questões de múltipla escolha, para conhecer o comportamento do consumidor estudado. Foi montada uma matriz para registrar a quantidade de respostas para cada opção. Depois dos dados coletados foi calculado o percentual de cada resposta e feito o gráfico correspondente.

\subsection{População e amostra}

Os 200 professores do ensino fundamental e médio lotados em 06 escolas particulares localizadas no bairro Jundiaí da cidade de Anápolis constituem os participantes desta pesquisa. É importante esclarecer que uma das 06 escolas devolveu os questionários em branco, de acordo com a diretora os professores não quiseram participar da pesquisa.

A população amostral refere-se aqueles 97 educadores que efetivamente participaram respondendo o questionário no momento e local da realização da pesquisa.

Conhecer as práticas de consumo dos professores foi considerado estratégico para este estudo, pois os educadores trabalham com a construção do conhecimento e também influenciam na formação de futuros consumidores.

A escolha da população que serviu de base para este estudo deve ser entendida como "[...] um conjunto de elementos (empresas, produtos, pessoas) que possuem características que serão objeto de estudo. A população amostral ou amostra, por sua vez, corresponde a uma parte da população escolhida de acordo com algum critério de representatividade. (VERGARA, 2000).

\subsection{Instrumento de pesquisa}

Para a realização desta pesquisa foi utilizado um questionário estruturado, que em primeiro plano tem os dados pessoais do pesquisado, utilizado para traçar o 
perfil do consumidor e na sequência 15 perguntas de múltipla escolha, sendo esta parte adaptada do modelo utilizado pelo Instituto Akatu no "Teste do Consumidor Consciente", disponibilizado no site daquele instituto.

Depois de adotados os procedimentos de escolha das unidades de ensino particular do bairro Jundiaí, descrito em detalhes no item 3.4, foram contatadas sete escolas, porém a diretora de uma das escolas foco informou que os educadores daquela escola não poderiam participar da pesquisa/responder o questionário porque estavam no início de ano letivo e os alunos demandavam toda a atenção dos professores. Então restaram seis escolas dispostas a participar da pesquisa. Assim foi agendada visita em cada unidade escolar para distribuir os questionários e esclarecer qualquer dúvida a respeito da pesquisa. Cada escola recebeu um número de questionários proporcional à quantidade de professores ali lotados. No total foram distribuídos 200 questionários entre as seis escolas escolhidas.

Segundo Gil (2007), "[...] o questionário constitui o meio mais rápido e barato de obtenção de informações, além de não exigir treinamento de pessoal e garantir o anonimato." Assim o questionário mostrou-se um instrumento apropriado, considerando que foi disponibilizado para os professores e recolhido pela direção das escolas.

Além disso, tornou-se "[...] útil para a obtenção de informações acerca do que a pessoa 'sabe, crê ou espera, sente ou deseja, pretende fazer, faz ou fez' [...]'. (SELLTZ, apud GlL, 2007, p. 115).

\subsection{Procedimentos de coleta e de análise de dados}

Para coletar informação sobre a quantidade de escolas particulares existentes na cidade fez-se uma visita à Sub Secretaria de Educação do Estado, que encaminhou via e-mail a relação das escolas com os respectivos endereços e telefones.

Anápolis conta com 80 escolas particulares e 10 escolas conveniadas/subsidiadas, que atendem do ensino infantil ao ensino médio. Diante de um volume tão grande, a opção foi feita para escolas que atendessem o ensino fundamental e médio. A tarefa ainda se mostrou enorme e, considerando a escassez de tempo para realização da pesquisa, foi feita uma estratificação por bairro. Foi escolhido o bairro Jundiaí, de forma aleatória. Neste bairro existem dez instituições 
particulares de ensino, aplicando a regra de exclusão do ensino infantil, restaram sete escolas.

Em sequência deu-se início ao contato telefônico com as escolas foco, para agendar visita e explicar aos diretores o objetivo da pesquisa.

Nesta etapa preliminar, uma diretora informou que seus educadores não poderiam responder o questionário/participar da pesquisa, porque estavam no início de ano letivo e os alunos demandavam toda a atenção dos professores. Em cinco escolas a direção demonstrou interesse e se prontificou em distribuir e recolher os questionários entre o corpo docente, ressaltando que precisariam de dez a quinze dias úteis para contatar todos os educadores. Na última escola visitada, a diretora deixou transparecer certa resistência, disse que tentaria, mas fazia questão de esclarecer que os professores não gostavam muito de participar de pesquisas, porém ficou com os questionários e pediu que retornasse para buscá-los em dez dias úteis. O retorno ocorreu no prazo, contudo, a diretora informou que não tivera tempo para distribuir o questionário entre os educadores daquela instituição de ensino e pediu mais cinco dias para fazê-lo. No segundo retorno, os questionários foram devolvidos em branco; de acordo com a diretora os professores não quiseram responder o questionário, o que de certa forma comprometeu a taxa de retorno da pesquisa.

Todo este processo para a coleta de dados ocorreu no período de 16/02 à 14/03/2011.

Foram recebidos noventa e sete questionários respondidos de um total de duzentos que haviam sido distribuídos entre as seis escolas do bairro Jundiaí. 


\section{RESULTADOS E DISCUSSÃO}

\subsection{Análise dos resultados - Perfil do consumidor}

Para traçar o perfil dos consumidores pesquisados foram consideradas as seguintes variáveis: sexo, idade, escolaridade e renda.

Os gráficos a seguir apresentam os resultados do perfil do consumidor conforme as variáveis acima.

\section{Gráfico 1 - Apresentação dos respondentes segundo o sexo.}

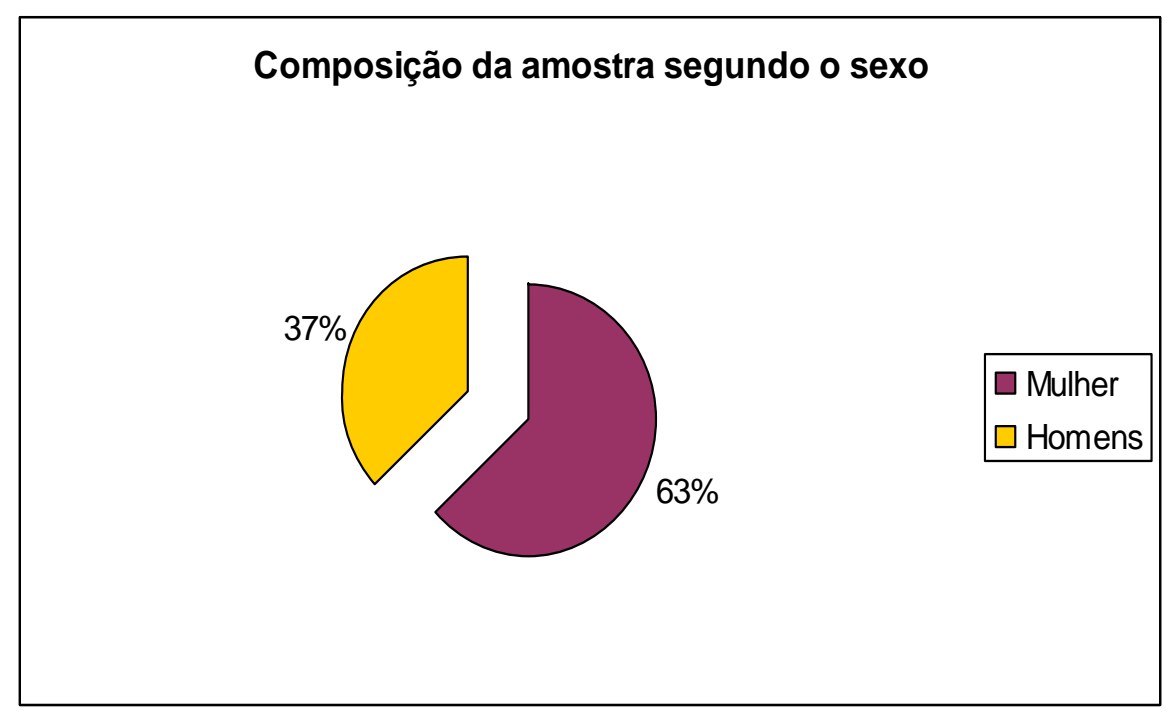

Fonte: Dados coletados pela autora. Anápolis, 2011.

Quanto ao sexo, ficou evidente que maioria da população amostral é constituída por mulheres, que representam $63 \%$, enquanto os homens representam $37 \%$. Torna-se pertinente lembrar que as decisões de consumo estão ligadas a forma de pensar e agir de cada indivíduo. Considerando que homens e mulheres pensam e agem de forma diferente podemos concluir, por analogia, que as características do comportamento feminino sobressaíram nos resultados desta pesquisa. 


\section{Gráfico 2 - Apresentação dos respondentes segundo a faixa etária.}

\section{Composição da amostra segundo a faixa etária}

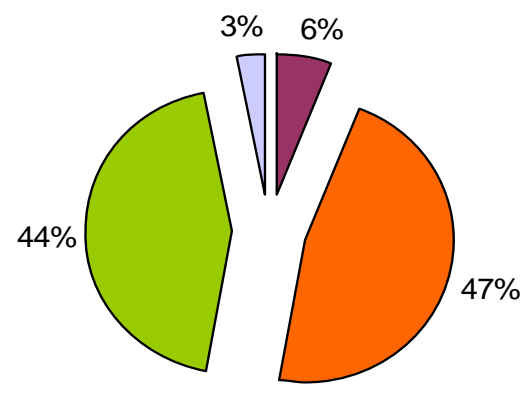

Fonte: Dados coletados pela autora. . Anápolis, 2011.

Os respondentes apresentaram os seguintes percentuais em relação à idade: 6\% têm entre 18 e 24 anos, 47\% estão na faixa etária dos 25 a 34 anos, 44\% estão entre 35 a 49 anos e 3\% possuem entre 50 e 60 anos. Neste caso, o perfil predominante é de um consumidor adulto jovem e de meia idade.

\section{Gráfico 3 - Apresentação dos respondentes segundo a escolaridade}

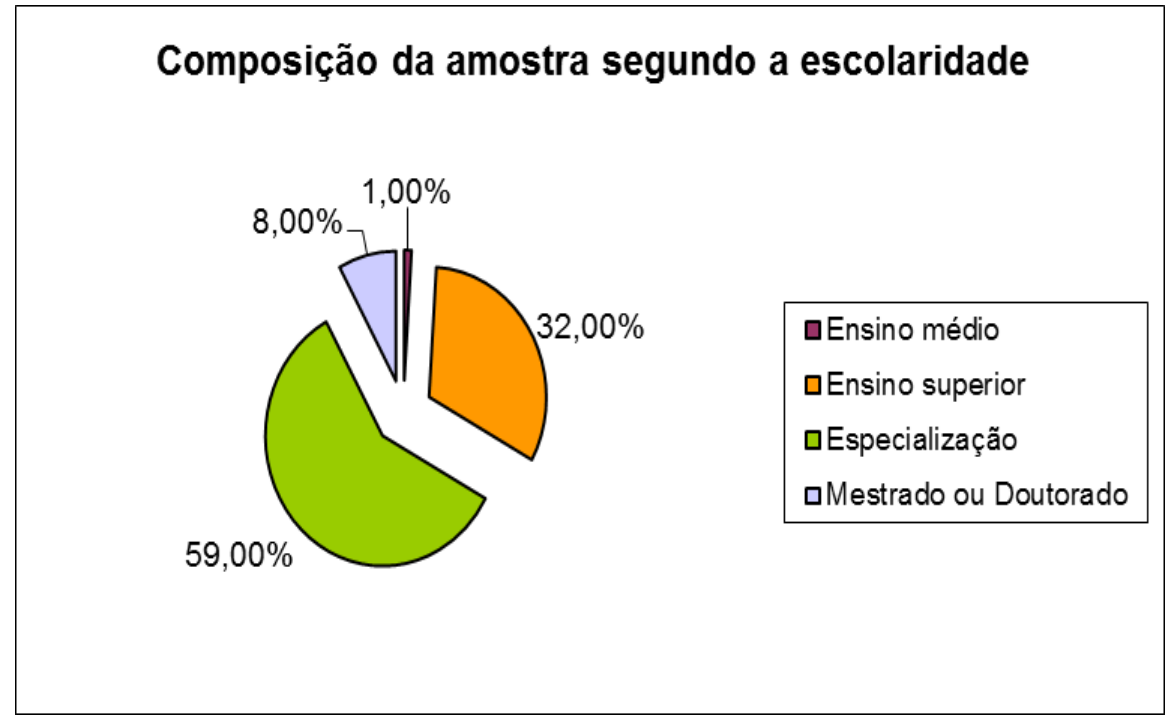

Fonte: Dados coletados pela autora. Anápolis, 2011. 
No tocante ao grau de escolaridade, $1 \%$ possui ensino médio, $32 \%$ ensino superior, $59 \%$ fizeram especialização, $8 \%$ tem mestrado ou doutorado. Esse fato indica um público consumidor com alto grau de instrução e informação.

\section{Gráfico 4 - Apresentação dos respondentes segundo a renda.}

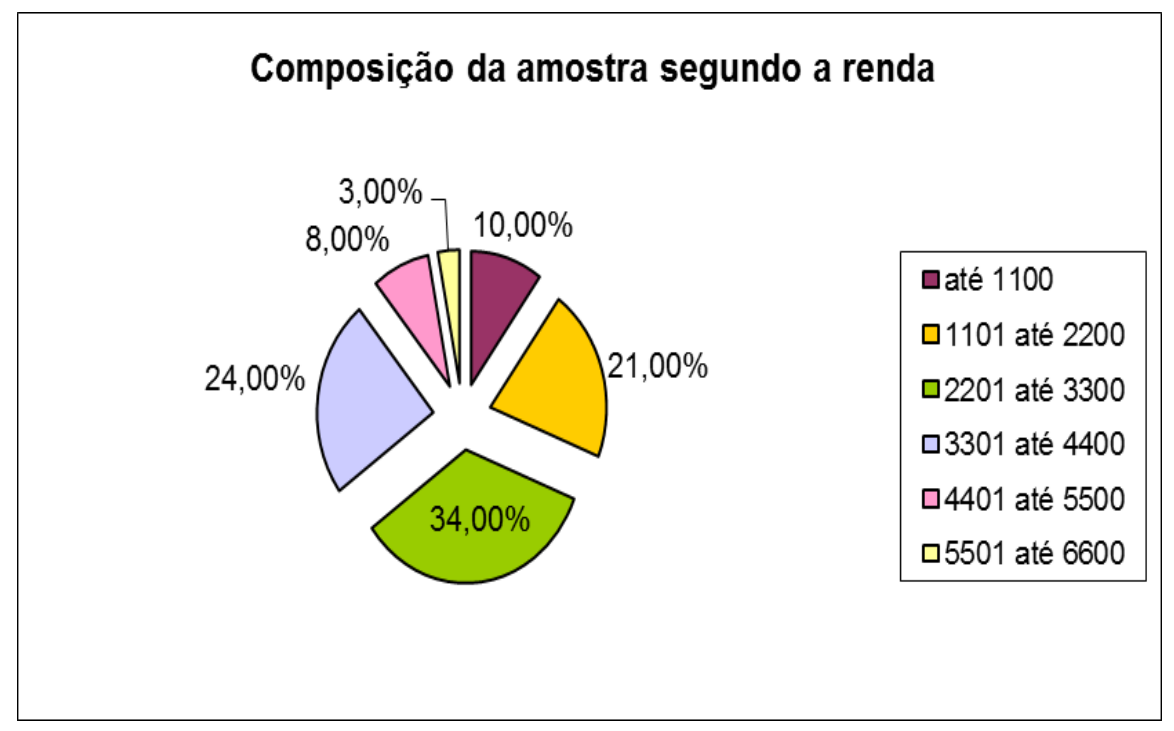

Fonte: Dados coletados pela autora. Anápolis, 2011.

Em relação à faixa salarial, $10 \%$ ganham até 1.100 reais, $21 \%$ recebem de 1101 até 2.200 reais, 34\% estão na faixa de 2201 a 3300 reais, $24 \%$ ganham de 3301 a 4400 reais, $8 \%$ recebem entre 4401 e 5.500 reais e $3 \%$ estão na faixa de 5501 a 6600 reais. Os dados indicam que a grande maioria recebe entre 4 e 10 salários mínimos, assim é possível concluir que possuem um poder de compra relativamente alto, comparado ao piso salarial dos professores da rede pública que é de $R \$ 1.024,00$. 


\subsection{Conhecendo o comportamento do consumidor consciente em relação às compras}

Depois de identificado o perfil da população da pesquisa, partimos para a análise das questões relacionadas ao comportamento do consumidor e o consumo consciente.

O gráfico abaixo mostra a análise das atitudes dos consumidores pesquisados, no momento da compra, o conhecimento sobre o papel das empresas quanto à sustentabilidade corporativa e o grau de interesse em produtos e serviços que causam menor impacto ao meio ambiente. Neste gráfico as questões de 01 a 08 foram agrupadas visto que buscam conhecer as atitudes dos consumidores em relação às empresas e aos produtos no momento da compra.

Gráfico 5 - Análise do comportamento/atitudes

do consumidor em relação ao consumo consciente.

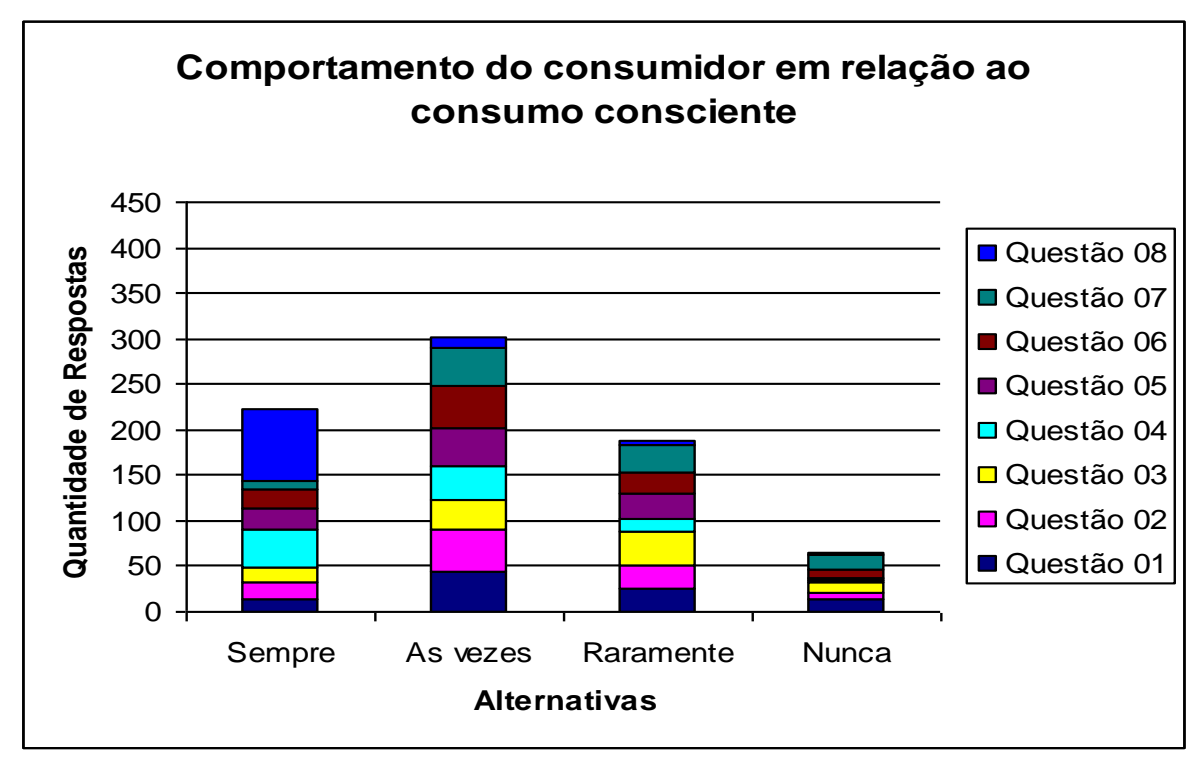

Fonte: Dados coletados pela autora. Anápolis, 2011.

Como se vê no gráfico acima, a opção "às vezes" ( $2^{a}$ coluna do gráfico) foi a que apresentou maior adesão por parte dos entrevistados. Desse modo os dados evidenciam que as atitudes de consumo consciente, abordadas nas oito questões iniciais, ainda não estão consolidadas entre os consumidores pesquisados.

$\mathrm{Na}$ sequência são apresentados os gráficos com o resultado da análise questão por questão de 01 a 08 do questionário. 
Gráfico 6 - Apresenta o resultado quanto à atitude relacionada com o conhecimento sobre o fabricante ou empresa que atua com responsabilidade social corporativa e acões de sustentabilidade.

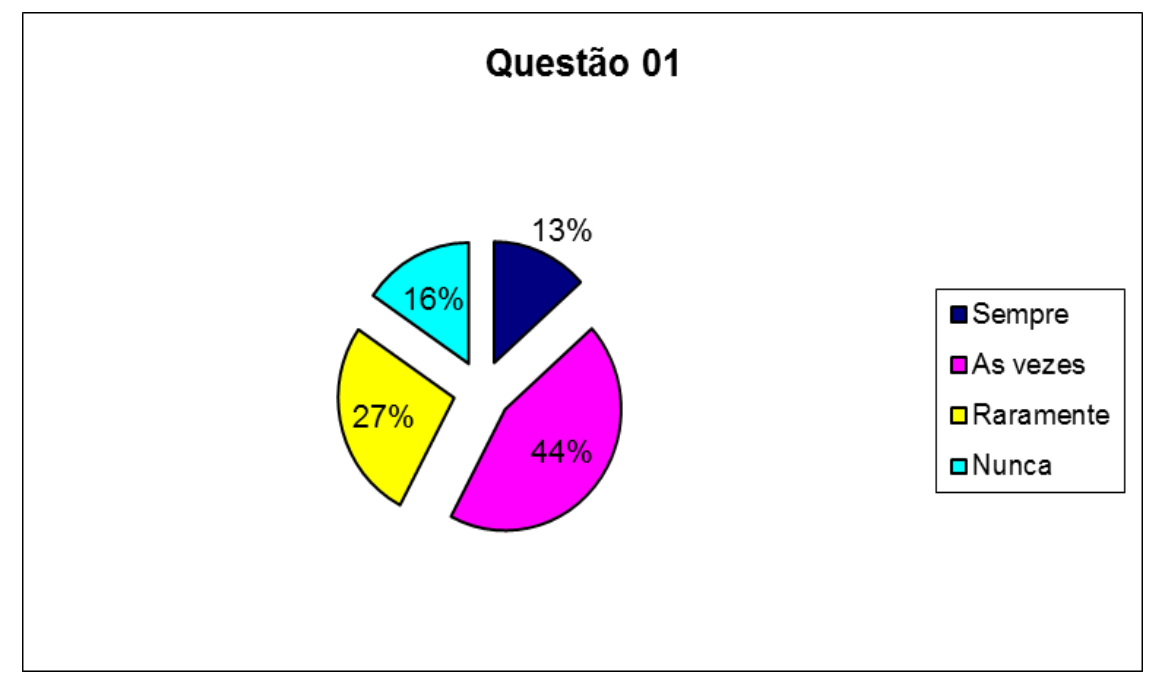

Fonte: Dados coletados pela autora. Anápolis, 2011.

O gráfico mostra que apenas $13 \%$ do universo pesquisado adotam "sempre" esse comportamento, enquanto $44 \%$ o fazem "às vezes", outros $27 \%$ "raramente" e $16 \%$ "nunca" buscam conhecimento sobre as organizações ambientalmente corretas.

Gráfico 7 - Apresenta o resultado do ato de compra de produtos e embalagens fabricados com material reciclado ou que podem ser recicláveis.

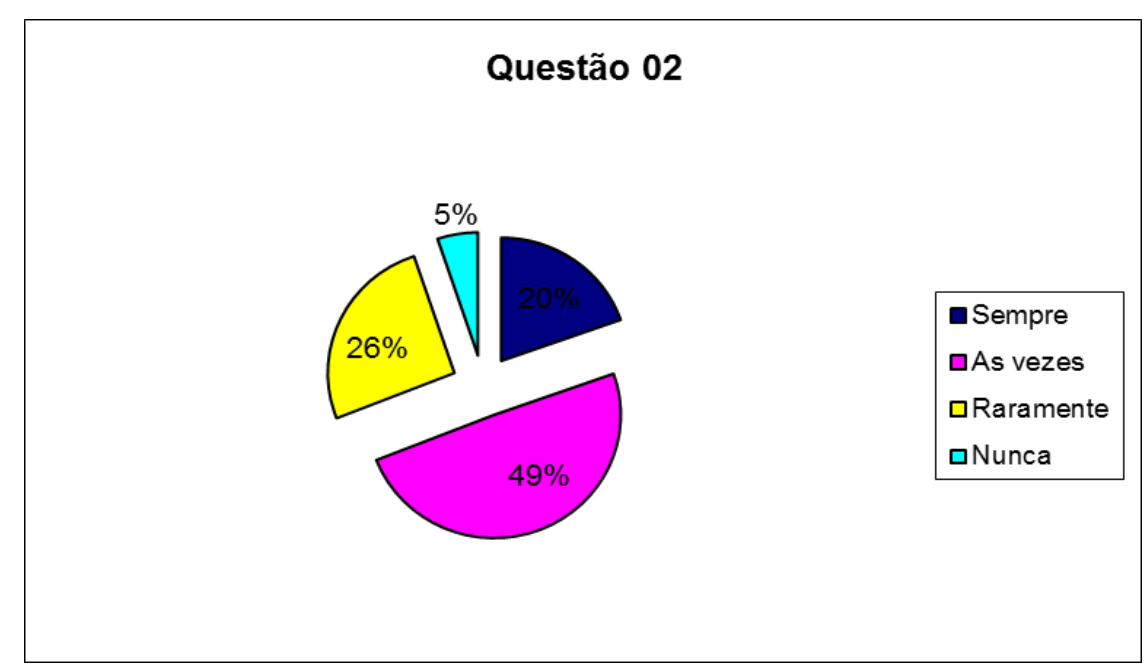

Fonte: Dados coletados pela autora. Anápolis, 2011. 
No quesito de compra de produtos com material reciclado ou que podem ser reciclados as respostas ficaram assim distribuídas: $20 \%$ "sempre", $49 \%$ "às vezes", $26 \%$ "raramente" e $5 \%$ "nunca". Os dados mostram que $75 \%$ dos respondentes adotam esta atitude vez em quando, o que pode indicar uma tendência em desenvolvimento. Neste quesito apenas $5 \%$ não demonstraram interesse nesta particularidade do produto adquirido.

\section{Gráfico 8 - Apresenta o resultado sobre o costume de verificar os rótulos e embalagens para identificar produtos ambientalmente correto.}

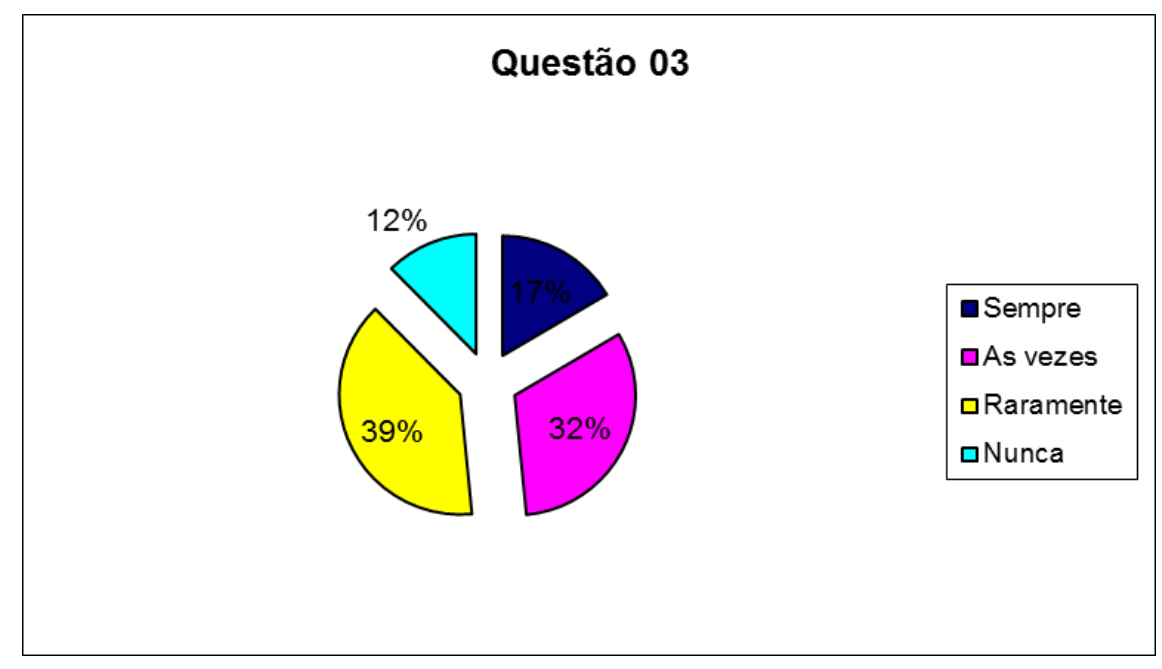

Fonte: Dados coletados pela autora. Anápolis, 2011.

O gráfico acima mostra que $17 \%$ responderam "sempre", $32 \%$ "às vezes", $39 \%$ "raramente" e $12 \%$ "nunca". Os dados evidenciam que esta prática ainda não é comum entre os pesquisados. 
Gráfico 9 - Apresentação do resultado quanto à motivação de comprar um produto por saber que ele foi fabricado de maneira ambientalmente correta.

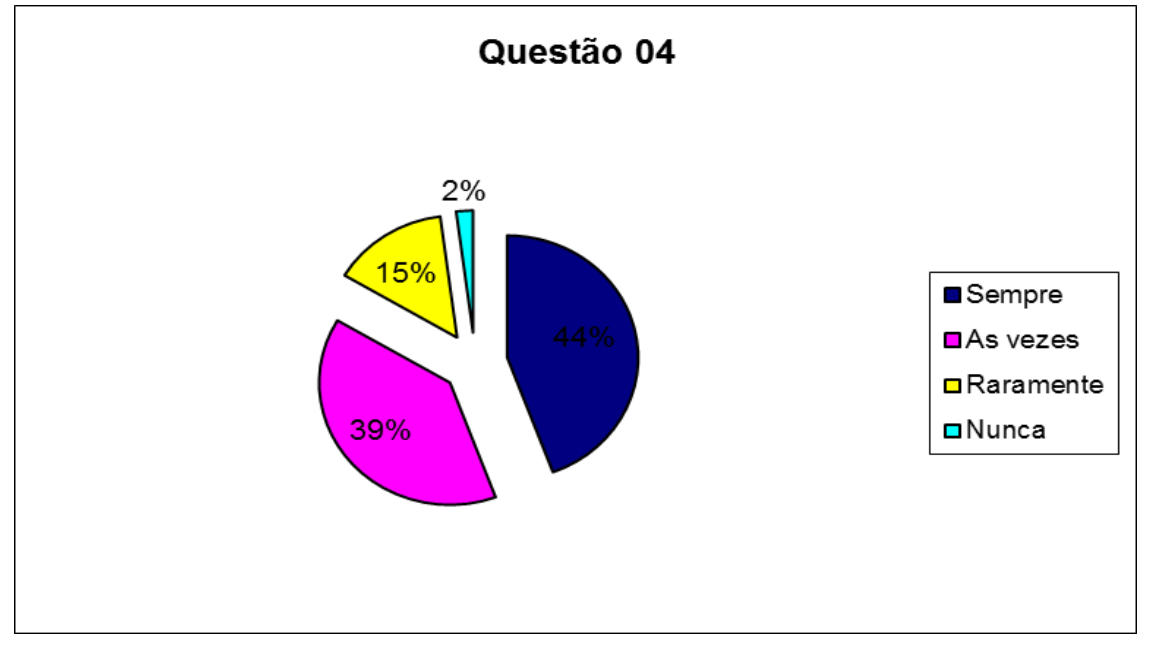

Fonte: Dados coletados pela autora. Anápolis, 2011.

Neste caso 44\% afirmaram que "sempre"; $39 \%$ responderam "às vezes", $15 \%$ disseram "raramente" e $2 \%$ responderam "nunca". Como $44 \%$ dos consumidores pesquisados afirmaram que ficam motivados a comprar um produto cujo processo de fabricação causou menor impacto ao meio ambiente, podemos concluir, neste caso, que esses consumidores demostram ações de consumo consciente.

Gráfico 10 - Apresentação dos resultados quanto a incentivar outros a comprar produtos de empresas que cuidam do meio ambiente, de seus funcionários, da sociedade e da comunidade onde estão inseridas.

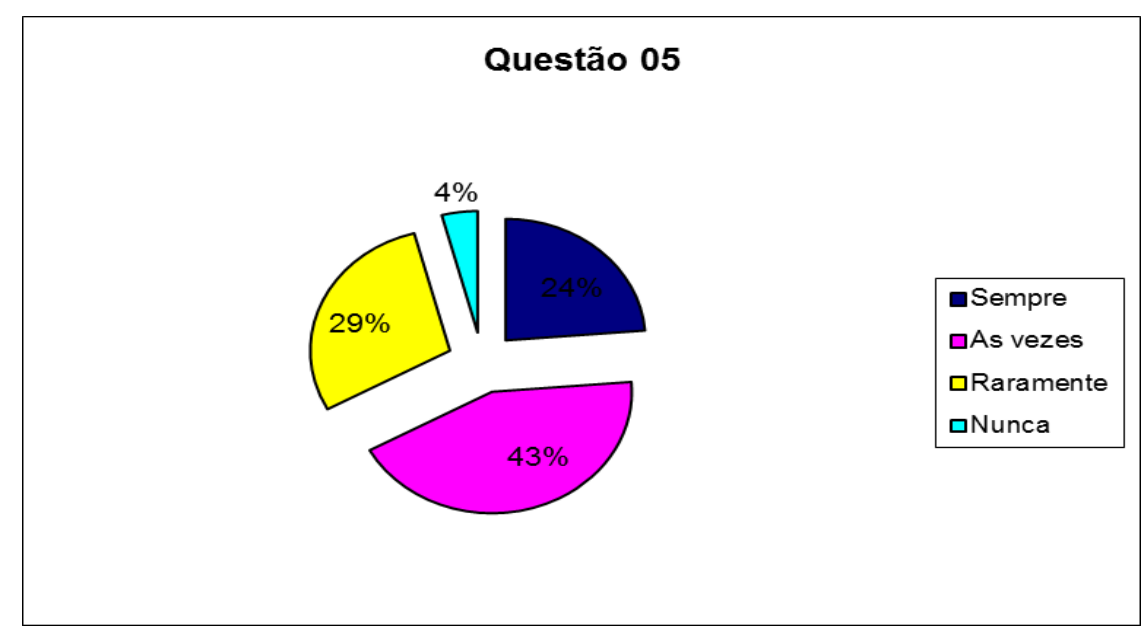

Fonte: Dados coletados pela autora. Anápolis, 2011. 
No gráfico acima, temos $24 \%$ "sempre", $43 \%$ "às vezes", $29 \%$ "raramente" e 4\% "nunca".

Desta forma, percebemos que $24 \%$ do universo pesquisado incentiva outros a comprar produtos de empresas que adotam ações de sustentabilidade, enquanto $67 \%$ ainda estão entre os que fazem às vezes e raramente e $4 \%$ responderam que nunca o fazem.

\section{Gráfico 11 - Apresentação dos resultados sobre comprar produtos de limpeza} biodegradáveis.

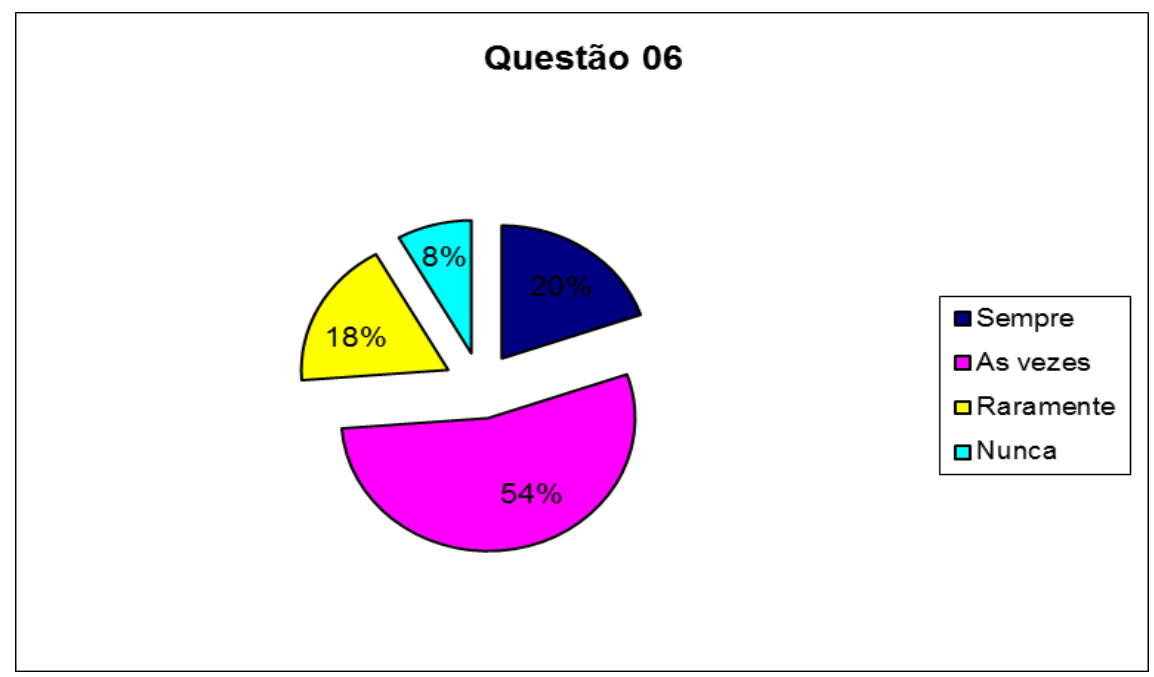

Fonte: Dados coletados pela autora. Anápolis, 2011.

Como pode ser visto no gráfico acima, as respostas dos pesquisados ficaram assim distribuídas: 20\% "sempre", 54\% "às vezes", 18\% "raramente" e $8 \%$ "nunca". Desse modo, concluímos que os consumidores ainda estão desenvolvendo esse comportamento já que $72 \%$ deles afirmaram que o fazem às vezes e raramente. 


\section{Gráfico 12 - Apresentação dos resultados sobre o costume de pagar mais por} um produto que não polui o meio ambiente.

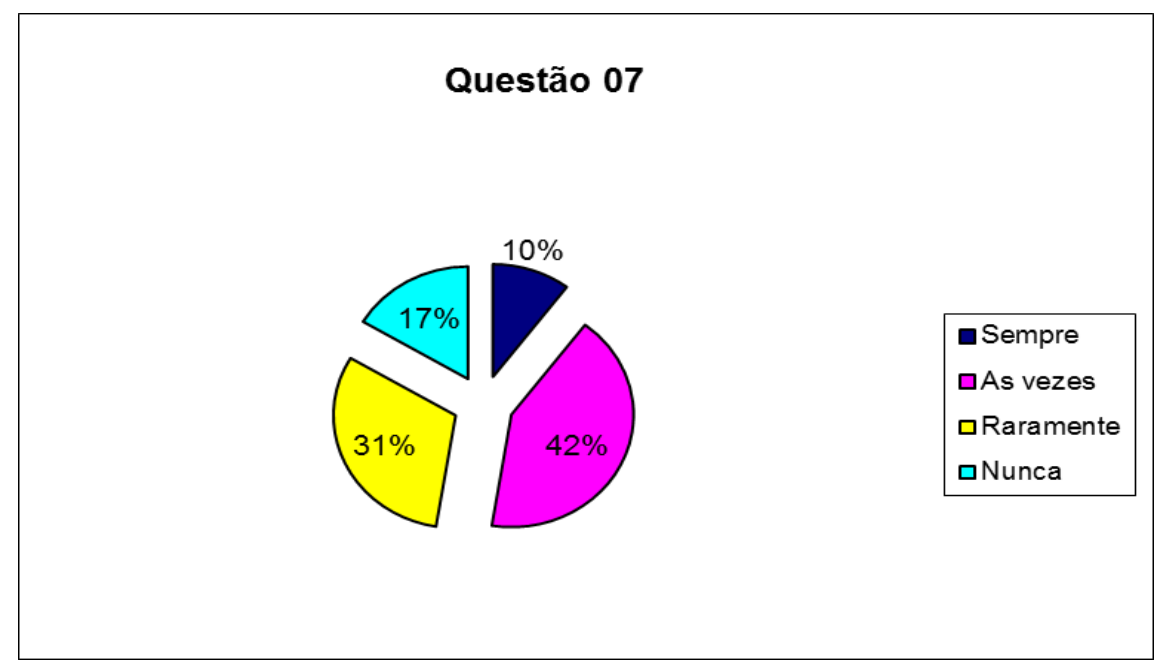

Fonte: Dados coletados pela autora. . Anápolis, 2011.

No gráfico acima obteve-se o seguinte resultado: 10\% estão "sempre" dispostos a pagar mais pelo produto, $42 \%$ responderam que "às vezes" pagam, $31 \%$ disseram que "raramente" pagam e 17\% afirmaram que "nunca" estão dispostos a pagar mais por um produto que não polui o meio ambiente.

Com base nesses dados, verifica-se que entre os consumidores pesquisados, aqueles que acreditam que não precisam pagar nenhum acréscimo por produtos ambientalmente corretos é quase o dobro dos que estão dispostos a fazê-lo. Atualmente os produtos ecologicamente corretos estão em evidência e são um diferencial de sustentabilidade corporativa. Contudo, ao observar o gráfico 12 é possível perceber que quando envolve um gasto maior, estes produtos não exercem grande influência sobre a escolha dos consumidores estudados. 
Gráfico 13 - Apresentação dos resultados sobre o costume de comprar lâmpadas e eletrodomésticos que gastam menos energia.

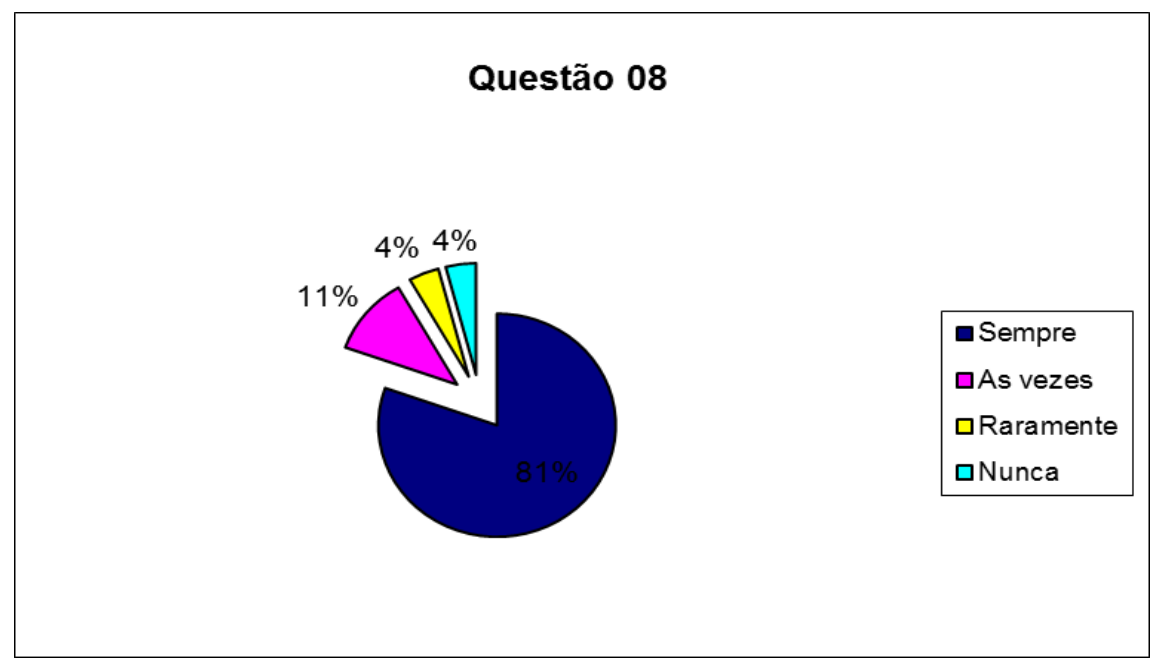

Fonte: Dados coletados pela autora. Anápolis, 2011.

O gráfico 13 apresenta uma atitude consolidada entre os consumidores pesquisados, a grande maioria, $81 \%$ afirmaram que "sempre" optam por produtos que economizam energia, $11 \%$ disseram "às vezes", $4 \%$ responderam "raramente" e $4 \%$ disseram que "nunca" fazem a opção por esses produtos.

Vamos comparar os gráficos 12 e 13 sob a ótica da economia, ações que geram impacto direto no bolso do indivíduo, isto é, aumentam ou reduzem os custos financeiros.

Ao analisar estes comportamentos, é possível notar que aqueles que contribuem para maior economia - redução de custos - são os mais praticados, neste caso, com percentuais acima de $80 \%$ de consumidores que "sempre" os adotam. Em contrapartida os que envolvem maior desembolso, gráfico 12, apresentam menor adesão, neste caso, apenas 10\% dos consumidores "sempre" o adotam.

\subsection{Conhecendo o comportamento do consumidor através das}

\section{suas práticas diárias relacionadas ao consumo consciente.}

O gráfico abaixo mostra a análise do comportamento dos consumidores pesquisados, através de seus hábitos diários, relacionados às características de consumo consciente, que impactam o próprio indivíduo, o meio ambiente e também 
suas relações sociais. No gráfico abaixo podemos ter uma visão panorâmica das questões de 09 a 15.

\section{Gráfico 14 - Análise do comportamento do consumidor através das suas práticas diárias relacionadas ao consumo consciente.}

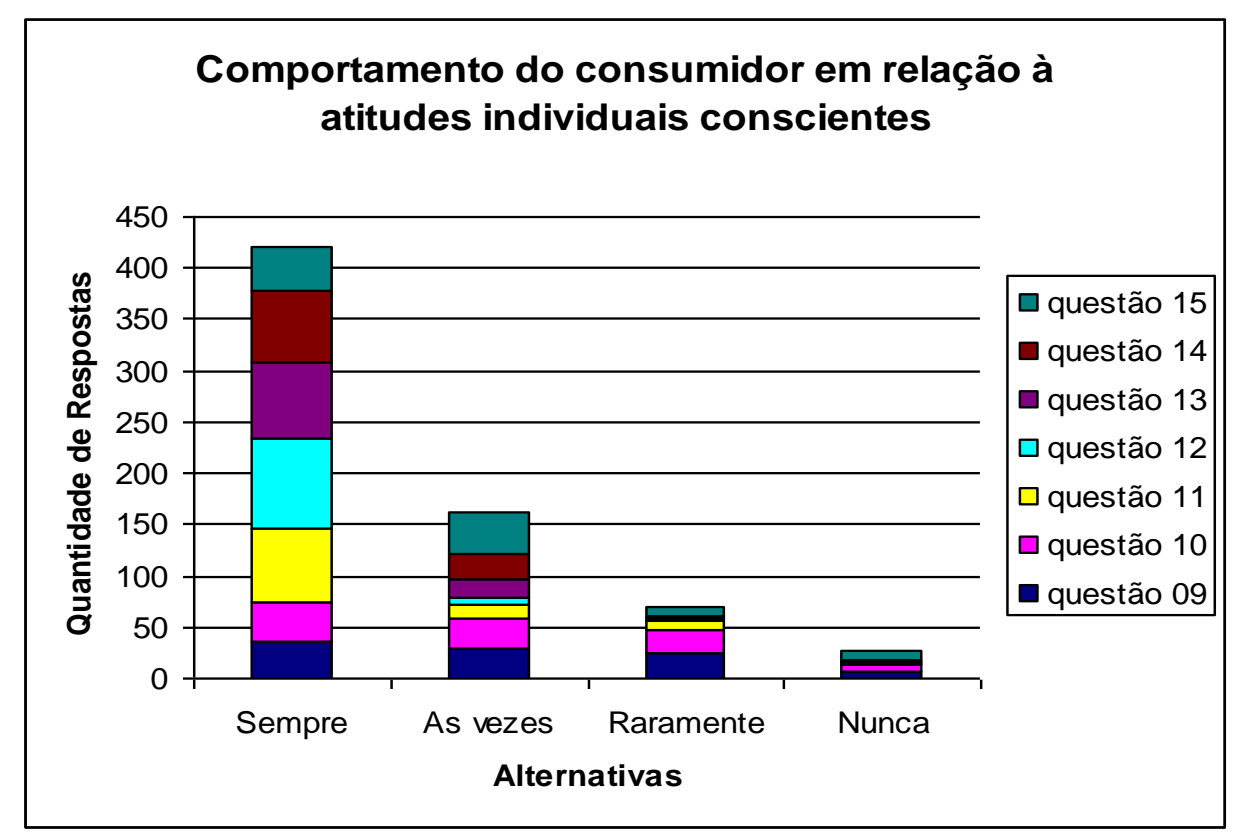

Fonte: Dados coletados pela autora. Anápolis, 2011.

As ações conscientes relacionadas ao manejo correto do lixo, ao uso racional de água e energia e outros hábitos de consumo que independem do ato de comprar são práticas bem comuns entre os entrevistados, como pode ser visto na primeira coluna, opção "sempre", do gráfico acima.

Porém, quando analisamos separadamente cada questão, verificamos que até mesmo os atos simples, como reutilizar e separar o lixo para reciclagem, ainda são pequenos. 
Gráfico 15 - Apresentação dos resultados sobre reutilização de produto, antes de jogá-lo no lixo.

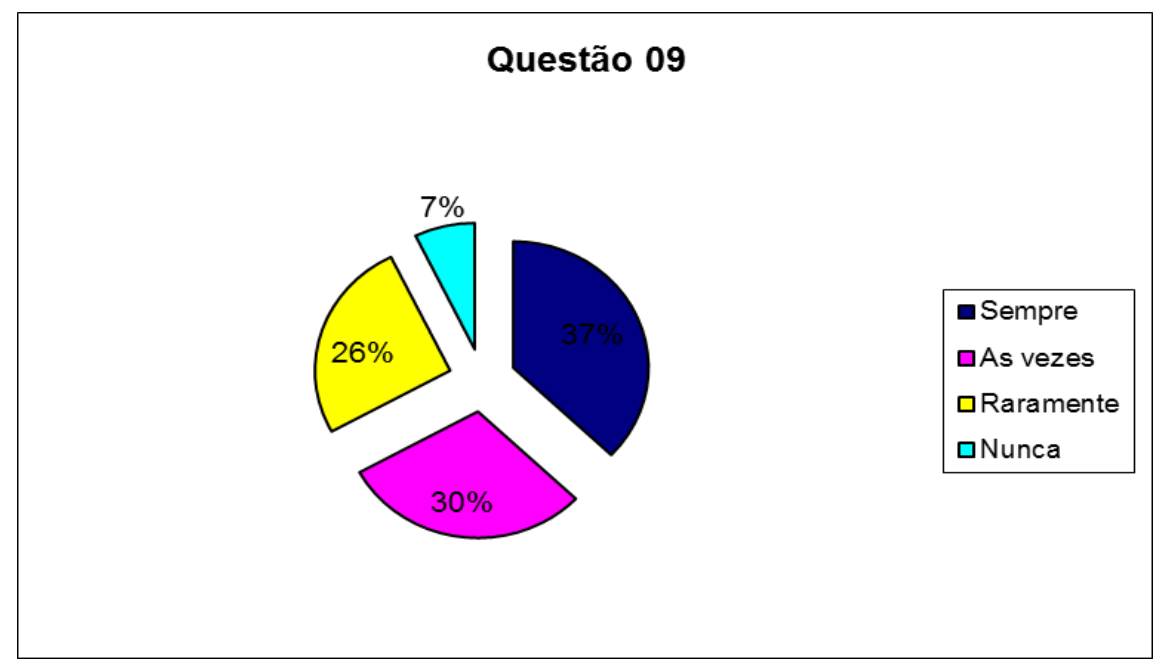

Fonte: Dados coletados pela autora. Anápolis, 2011.

Como pode ser visto no gráfico 15, os que responderam "sempre" corresponde a $37 \%$ dos pesquisados, $30 \%$ disseram "às vezes", $26 \%$ afirmaram que "raramente" e 7\% responderam que "nunca" adotam essa prática.

Gráfico 16 - Apresentação dos resultados sobre coleta seletiva, separação do lixo para reciclagem.

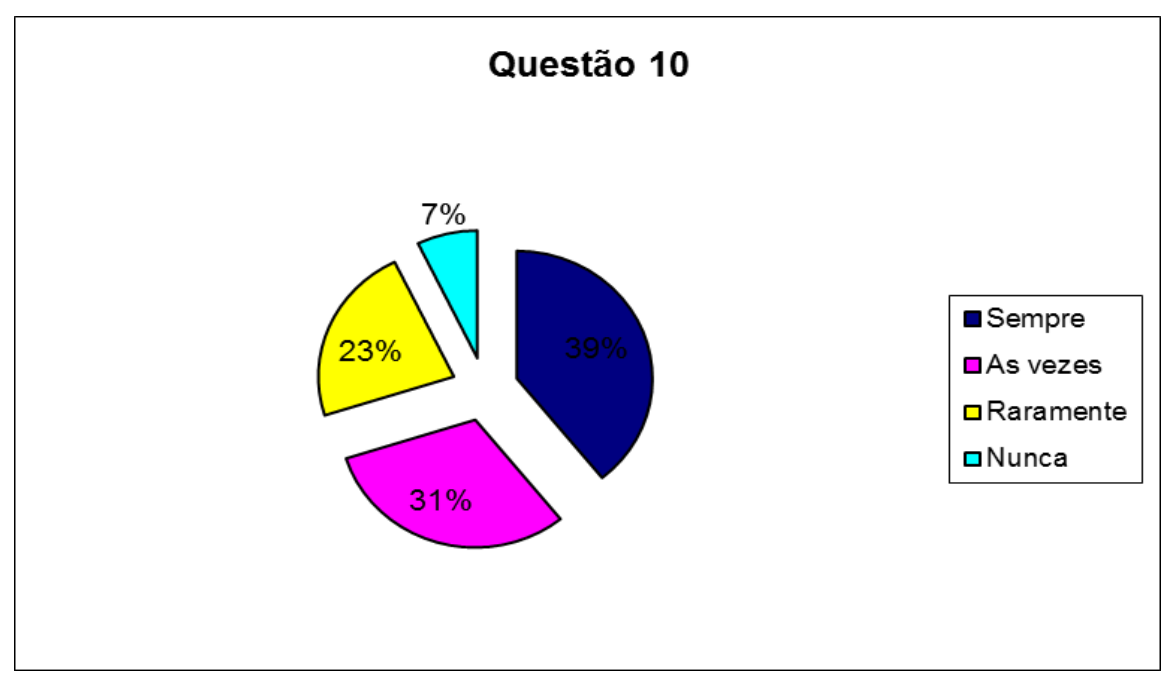

Fonte: Dados coletados pela autora. Anápolis, 2011.

O gráfico mostra que separar/preparar o lixo para reciclagem, isto é, praticar a coleta seletiva, ainda não é uma prática consistente entre os educadores pesquisados. As respostas estão assim distribuídas: 39\% fazem "sempre", $31 \%$ 
fazem "às vezes", $23 \%$ fazem "raramente" e $7 \%$ dos respondentes disseram que "nunca" separam o lixo para a reciclagem. Desse modo, temos $61 \%$ que não fazem regularmente, contra os $39 \%$ que afirmaram "sempre" adotarem a prática da coleta seletiva.

Assim sendo, é possível concluir que o nível de preocupação com manejo do lixo e consequente preservação ambiental ainda é baixa, visto que a maioria não demonstrou preocupação com os impactos ambientais causados pelo lixo jogado nos lixões ou nos aterros sanitários, a ponto de induzi-los a um ato simples de separar o que pode ser reciclado.

\section{Gráfico 17 - Apresentação dos resultados sobre evitar a queima do lixo doméstico.}

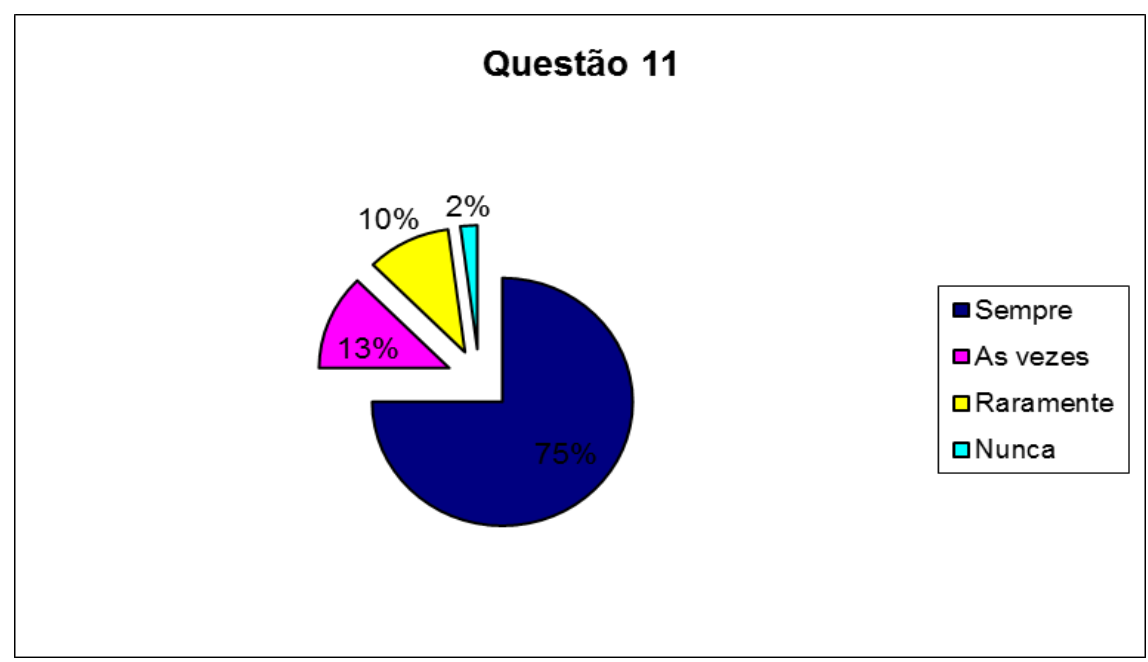

Fonte: Dados coletados pela autora. Anápolis, 2011.

O resultado mostra um percentual de $75 \%$ de consumidores conscientes, que "sempre" evitam a queima de lixo doméstico, contudo, 13\% afirmaram que evitam "às vezes", $10 \%$ responderam "raramente" e $2 \%$ afirmaram que "nunca" evitam tal prática. Assim, $25 \%$ dos consumidores pesquisados ainda insistem no hábito de queimar lixo doméstico.

Essa prática de eliminar o lixo através das queimadas causa impacto ambiental e também à saúde, pois a fumaça gerada é formada de gás carbônico, e esse gás é um dos grandes responsáveis pelo aumento do efeito estufa e do aquecimento global. Além disso, também traz problemas para a saúde humana, sendo as doenças respiratórias as mais comuns. 
Gráfico 18 - Apresentação dos resultados quanto a preocupação de não jogar lixo na rua.

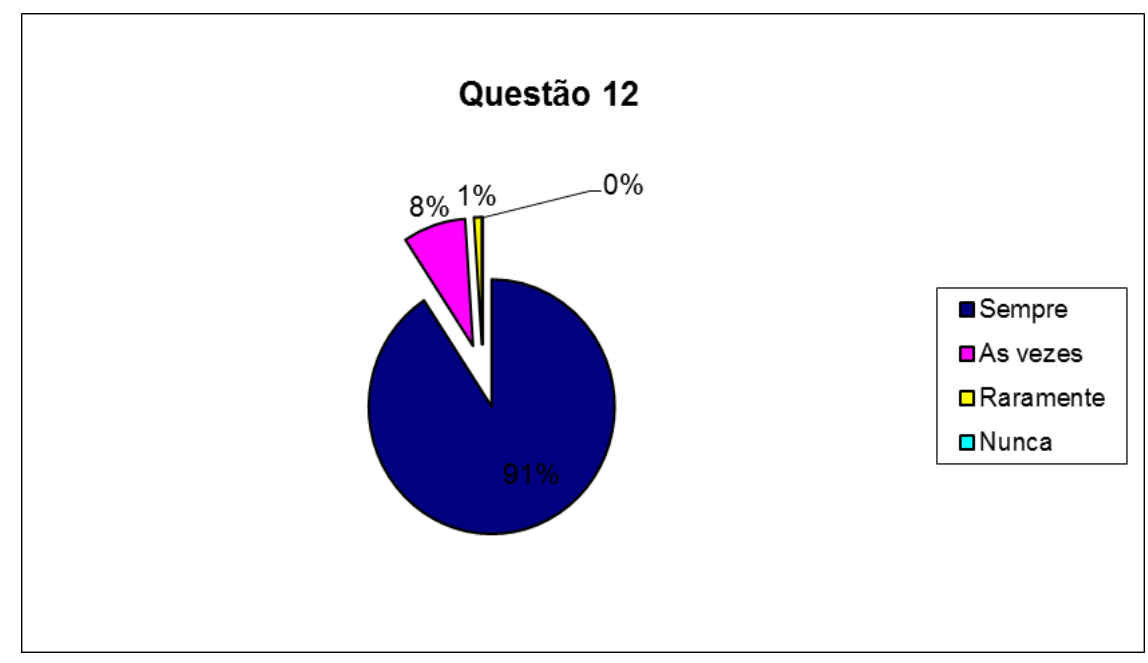

Fonte: Dados coletados pela autora. Anápolis, 2011.

Ao analisar esta prática comportamental, constatamos que $91 \%$ dos consumidores "sempre" demonstram preocupação em não jogar lixo na rua, 8\% o fazem "às vezes" e $1 \%$ disse que "raramente" o faz. Esses dados são confirmados pela observação do gráfico acima. Esta prática foi a que teve maior adesão dos pesquisados e não obteve nenhuma resposta para a opção "nunca".

Gráfico 19 - Apresentação dos resultados sobre não deixar a torneira aberta ao escovar os dentes ou ao fazer a barba.

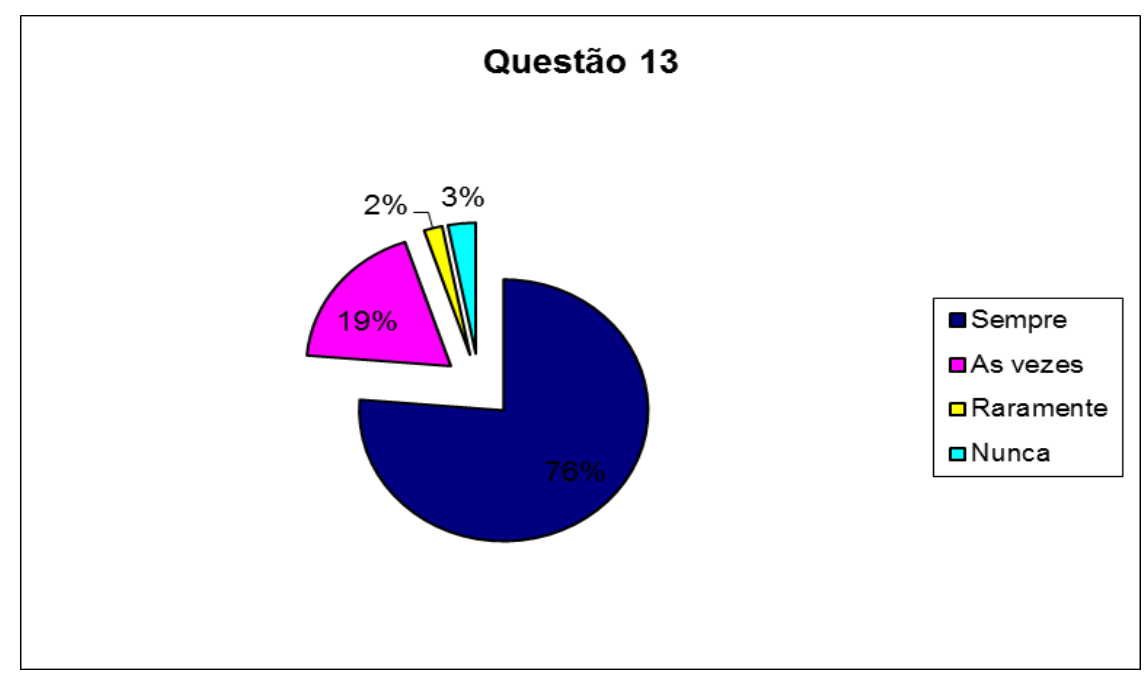

Fonte: Dados coletados pela autora. Anápolis, 2011. 
Ao abordar o uso racional de água, ou a prática que evita o desperdício deste recurso natural essencial para a vida, o gráfico acima nos mostra que $76 \%$ dos respondentes afirmam que "sempre" fecham a torneira, $19 \%$ somente "às vezes", $2 \%$ "raramente" e $3 \%$ "nunca".

\section{Gráfico 20 - Apresentação dos resultados sobre apagar as luzes e os aparelhos eletrônicos quando não estão em uso.}

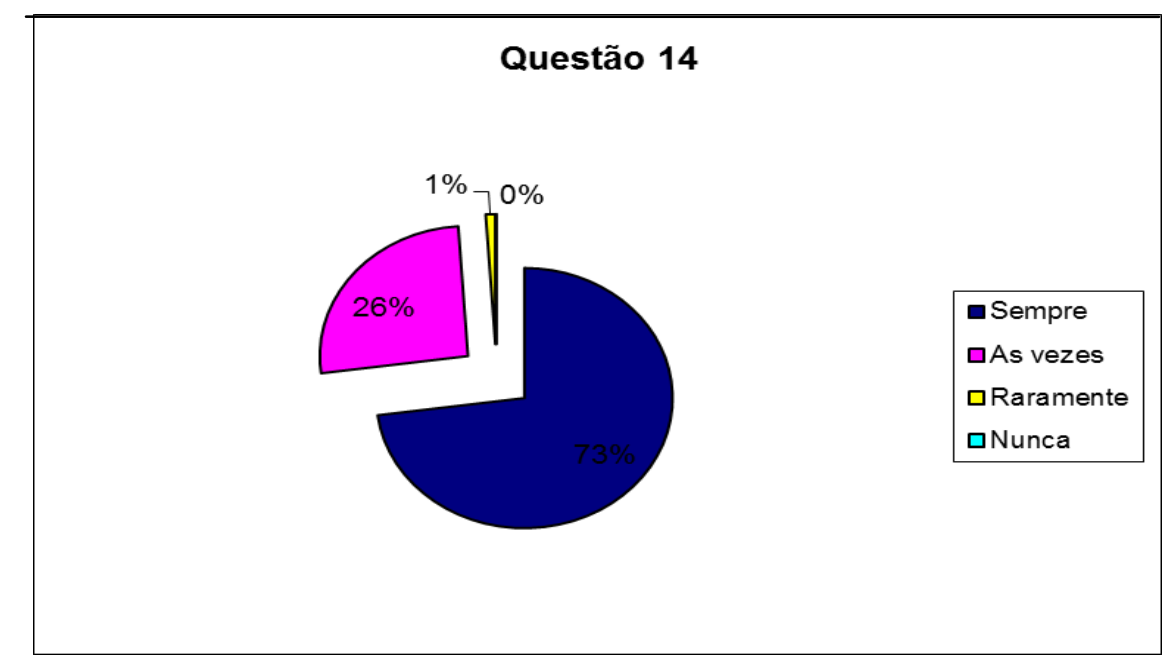

Fonte: Dados coletados pela autora. Anápolis, 2011.

O gráfico acima mostra que $73 \%$ adotam "sempre" esse hábito, enquanto $26 \%$ só "às vezes", e $1 \%$ "raramente" adotam a prática do uso racional de energia. Neste caso também não houve a ocorrência da opção "nunca".

Gráfico 21 - Apresentação dos resultados sobre orientar as pessoas sobre os cuidados com o meio ambiente.

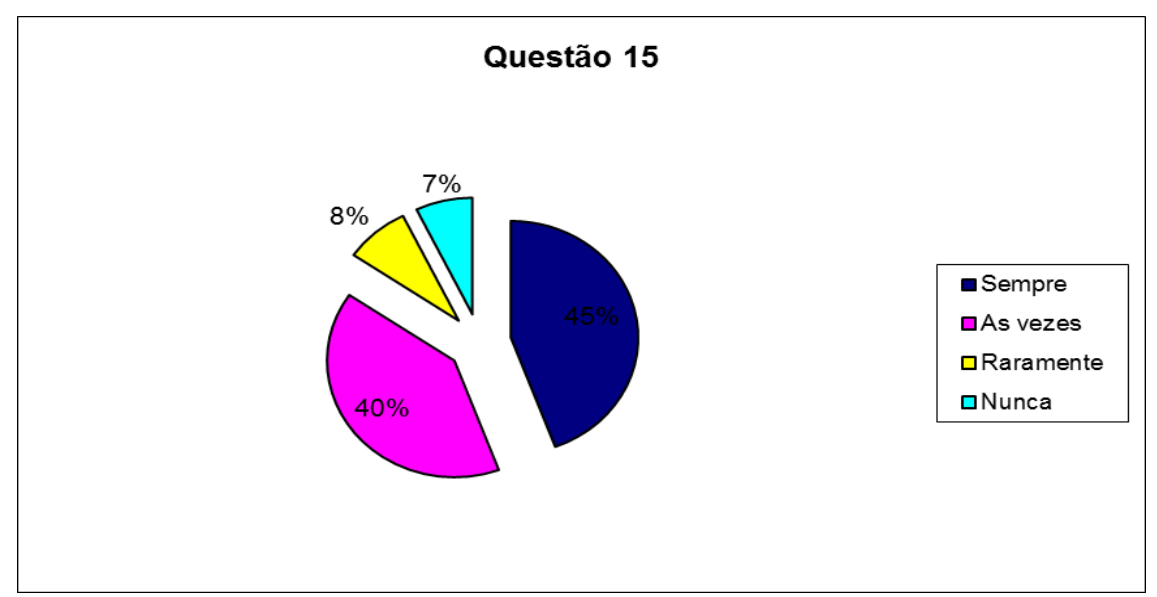

Fonte: Dados coletados pela autora. Anápolis, 2011. 
Como podemos ver no gráfico acima, $45 \%$ dos educadores pesquisados responderam "sempre", 40\% "às vezes", $8 \%$ "raramente" e $7 \%$ afirmaram que "nunca" orientam outras pessoas sobre os cuidados com o meio ambiente. Os dados indicam que os professores objeto desta pesquisa ainda estão consolidando em sua rotina a atitude de ser um multiplicador de práticas sustentáveis.

Nos últimos anos, muitas pesquisas foram realizadas no Brasil, com o objetivo de conhecer o comportamento do cidadão em relação ao consumo consciente, bem como o seu grau de envolvimento com a atuação das organizações no tocante a Responsabilidade Social Corporativa e ações voltadas para o Desenvolvimento Sustentável. (ETHOS, AKATU, ISER). Nestes moldes, nos anos de 2004 e de 2010 foram realizadas duas pesquisas, sob a coordenação do Instituto Ethos em parceria com o Instituo Akatu. Estes estudos mostraram que o consumidor brasileiro está mais consciente da sua responsabilidade nas questões socioambientais. Os dados mostraram também que este consumidor consciente conhece as empresas que atuam com responsabilidade socioambiental e as valorizam dando preferências para seus produtos, e ainda incentivam outras pessoas a fazer o mesmo.

De fato, quando o consumidor adota essa postura consciente ele está privilegiando "[...] não apenas preço e qualidade, mas principalmente, o comportamento social das empresas fabricantes desses produtos". ( TACHIZAWA, 2009, p.5).

Quando os educadores anapolinos foram questionados sobre o hábito de conhecer e valorizar empresas e produtos que buscam causar menor impacto ambiental, as respostas indicaram baixo índice de adesão a essas práticas que oscilaram entre $10 \%$ e $24 \%$ dos pesquisados.

Foi possível verificar também que o preço do produto ainda é um forte estímulo para sua aquisição, pois embora $44 \%$ do universo pesquisado tenha afirmado que "sempre" ficam motivados a comprar produtos ambientalmente corretos (gráfico 9), apenas $10 \%$ dos respondentes estão dispostos a pagar mais por esse produto (gráfico12).

Estes dados são relevantes ao considerarmos que a construção de uma sociedade ambientalmente sustentável, socialmente justa, e economicamente viável passa pelo desenvolvimento da consciência coletiva ao nível de "produzir mudanças nas suas próprias condutas, modificando, por exemplo, seus hábitos de consumo" 
(BARBIERI, 2004, p.77), mas indicam também a necessidade das organizações tornarem o processo produtivo mais eficiente, de modo que o produto chegue ao consumidor com um preço atrativo.

\section{Considerações Finais}

A sustentabilidade nas dimensões ambiental, econômica, social e as práticas do indivíduo sob a ótica do consumo colocam em discussão o atual modelo de produção e o excessivo consumo mundial. A exposição de que as ações humanas estão comprometendo a capacidade de sustentação dos ecossistemas da terra e consequentemente a qualidade de vida do ser humano, são fatos que devem impulsionar uma nova postura das pessoas na busca de alternativas menos impactantes do ponto de vista ambiental.

Assim sendo, tornou-se fundamental conhecer ações já realizadas e as que estão em andamento, já que a sustentabilidade pressupõe um fluxo permanente de ações, de todos os elos que formam a corrente - governos, organizações, sociedade - para buscar soluções que passam pela conscientização das pessoas sobre os problemas existentes e a necessidade de adotar práticas ambientalmente corretas como o uso racional dos recursos naturais, políticas públicas que busquem melhorar as condições sociais e preservação ambiental, investimentos em pesquisas, utilização de meios de produção menos poluentes, e adoção de práticas de consumo consciente.

Para verificar se os consumidores estão cientes do importante papel que exercem neste contexto, foi desenvolvida esta pesquisa que contou com 97 professores de ensino fundamental e médio, de 05 escolas particulares, localizadas no bairro Jundiaí, na cidade de Anápolis-GO. Através da análise dos dados coletados foi possível traçar o perfil destes consumidores e identificar as ações que fazem parte do seu cotidiano como consumidor consciente.

No estudo realizado, as mulheres são maioria absoluta, representando mais de sessenta por cento da população amostral. No tocante a faixa etária, noventa por cento dos pesquisados tem entre 25 e 49 anos, que revela consumidores adultos jovens e de meia idade. Quanto à escolaridade mais de cinquenta e oito por cento dos pesquisados já fizeram algum tipo de pós-graduação/especialização, donde podemos concluir que tratamos com pessoas com elevado grau de instrução e 
informação. Com relação a faixa salarial mais de setenta e oito por cento recebem entre 4 e 10 salários mínimos, indicando pessoas com um bom poder de compra.

A análise do comportamento do consumidor, no que se refere ao conhecimento prévio sobre empresas que desenvolvem ações de sustentabilidade socioambiental e a busca por produtos ambientalmente corretos ainda não se firmou como prática/hábito entre os pesquisados, apenas $13 \%$ e $20 \%$ respectivamente responderam "sempre", enquanto a maioria dos respondentes disse fazer isso "às vezes". Ainda é pequeno também o número de consumidores que estão dispostos a pagar mais por um produto que polui menos o meio ambiente, apenas $10 \%$ disseram que "sempre" o fazem.

Os educadores pesquisados demonstram certo grau de preocupação com o meio ambiente. Quanto ao uso racional de energia e água no ambiente doméstico, mais de $70 \%$ responderam "sempre" para as duas questões. E $81 \%$ responderam que "sempre" compram lâmpadas econômicas, e também compram eletrodomésticos com melhor eficiência energética. Neste caso, o benefício pessoal vislumbrado pelo consumidor parece ser um grande estímulo à adoção de determinadas práticas.

Por outro lado, não demonstram grande interesse em medidas relativamente simples, como separar o lixo para a coleta seletiva; esta prática pode amenizar os impactos ambientais causados pelo lixo. Entretanto apenas 39\% dos respondentes afirmaram que "sempre" o fazem. Embora 91\% tenha demonstrado preocupação quanto a jogar lixo na rua, fica evidente que a maioria dos pesquisados ainda precisa desenvolver esta prática salutar.

Para o Instituto Akatu, a coleta seletiva exige maior reflexão, mas é também um exercício de cidadania, através do qual os cidadãos exercem um papel ativo em relação à administração da cidade.

Torna-se oportuno lembrar que "Os padrões de consumo não estão apenas esgotando os elementos naturais existentes, como também estão contribuindo para sua degradação através dos resíduos e das emissões de substâncias nocivas." (GIDDENS, 2005, p. 487). Neste aspecto, o consumo consciente envolve mais do que apenas rever os padrões de consumo. É imperativo para o consumidor rever também seus conceitos e as ações em relação aos resíduos produzidos, em outras palavras, ao manejo correto do lixo. 
Quando perguntados se incentivam outros a comprar produtos de empresas que cuidam do meio ambiente, dos funcionários, da sociedade e da comunidade onde atuam apenas $24 \%$ responderam "sempre". Na questão sobre o costume de orientar as pessoas sobre os cuidados com o meio ambiente $45 \%$ afirmaram "sempre". Os dados indicam que os professores objeto desta pesquisa ainda não consolidaram de forma absoluta em sua rotina a atitude de valorizar o conhecimento, estimulando outros a construir uma realidade mais sustentável.

Os estudos científicos comprovaram que o futuro da biodiversidade do planeta e da própria humanidade depende de uma relação harmônica entre o homem e a natureza. Nessa ótica, o consumidor consciente é um ator fundamental. Ele detém o poder de escolha. Só ele pode escolher como e o que consumir e de que empresa comprar. A opção pelo consumo consciente contribui para construção de um planeta mais saudável e uma sociedade mais justa.

Este trabalho abre espaço para futuros estudos relacionado às práticas pedagógicas dos professores, isto é, entender como os educadores transmitem aos seus alunos as noções de consumo consciente, e em quais disciplinas os professores se sentem mais propensos a contextualizar sustentabilidade com o consumidor consciente. Propõe também uma investigação sobre a seguinte reflexão: o que induz um grupo de pessoas com alto grau de instrução, muita informação e grande potencial de convencimento a optar por ações pouco sustentáveis? 


\section{REFERÊNCIAS}

ALMEIDA, Fernando - Responsabilidade Social e Meio Ambiente - "Os desafios da Sustentabilidade" - PLT 2010 - Rio de Janeiro; Elsevier, 2009.

BARBIERI, J. C. Gestão Ambiental Empresarial: conceitos, modelos e instrumentos -2 ed. Atual e ampliada. São Paulo: Saraiva 2007. Desenvolvimento e meio ambiente: as estratégias de mudanças da Agenda. 7 ed. ver. e atual. Petrópolis, RJ: Vozes, 2005.

Gestão Ambiental Empresarial: Conceitos, Modelos e Instrumentos. São Paulo: Saraiva, 2004.

BRASIL - Constituição da República Federativa do Brasil. 1988.

EXAME. Guia Exame de Sustentabilidade, São Paulo. Disponível em: < http://www.portalexame.abril.com.br>, acesso em 10/05/2010.

Guia EXAME de Sustentabilidade 2010, São Paulo, Editora

Abril.

FBDS - Fundação Brasileira para Desenvolvimento Sustentável, disponível em www.fdb.org.br, acesso em 20/01/2011.

GIDDENS, Anthony - Sociologia; tradução Sandra Regina Netz, 6 ed., Porto Alegre: Artmed, 2005.

GIL, Antonio Carlos - Como Elaborar Projetos de Pesquisa. São Paulo: Atlas, 2007.

IBGE - Instituto Brasileiro de Geografia e Estatística - Indicadores de Sustentabilidade. Disponível em www.ibge.gov.br/indicadores/, acesso em 10/05/2010.

INSTIUTO AKATU - Práticas e Perspectivas da Responsabilidade Social Empresarial no Brasil, 2008. Disponível em www.akatu.org.br/akatu_açao/publicações/, acesso em 20/01/2011. 
INSTRUTO ETHOS, Indicadores Ethos de Responsabilidade Social. Disponível em: <http://www.ethos.org.br/docs/indicadores/resultados_2004>, acesso em $10 / 05 / 2010$

JACOBI, Pedro. Movimento ambientalista no Brasil. Representação social e complexidade da articulação de práticas coletivas. In Ribeiro, W. (org.). Publicado em Patrimônio Ambiental - EDUSP - 2003, disponível em: www.ufmt.br/gpea/pub/, acesso em 30/03/2011.

LAVILLE, Élisabeth - A Empresa Verde, São Paulo: ÕTE, 2009.

NASCIMENTO, Luiz F. - Gestão Ambiental e a Sustentabilidade, UAB/MEC, 2008.

OLIVEIRA, José Antonio Puppim de - Empresas na Sociedade - sustentabilidade e responsabilidade social. Rio de Janeiro: Campus, 2008.

LEI 6.938, disponível em www.planalto.gov.br/../Leis/L6938compilada.htm, acesso em 17/01/2011.

PNUD - Programa Nacional para o Desenvolvimento. Disponível em: < http://www.pnud.org.br/idh/1998>, acesso em 20/04/2010

RELATÓRIO BRUNDTLAN, disponível em <http/ www.mudançasclimaticas.andi.org.br/node/91, acesso em 20/10/2010.

SAMARA, S. B., MORSCH, M. A. Comportamento do Consumidor: Conceitos e Casos. São Paulo: Pearson Education, 2005 - PLT.

TACHIZAWA, Takeshy - Gestão Ambiental e Responsabilidade Social Corporativa: Estratégias de negócios focadas na realidade brasileira. 6 ed. rev. amp. São Paulo: Atlas, 2009.

URBAN, Tereza - Missão (quase) Impossível: aventuras e desventuras do movimento ambientalista no Brasil. São Paulo: Pierópolis, 2001. 


\section{APÊNDICE}

\section{QUESTIONÁRIO}

Prezado (a) Senhor (a),

Esta pesquisa tem por objetivo identificar ações e/ ou comportamento do consumidor consciente.

Este faz parte do Trabalho de Conclusão de Curso de Graduação em Administração de Empresa da Universidade de Brasilia - UnB.

Sua contribuição é muito importante para a condução do trabalho, pelo qual agradeço.

A pesquisa tem o objetivo de resguardar a identidade do participante, por isso não é necessário se identificar. Os dados pessoais informados serão utilizados para fins estatísticos e será preservando o sigilo da informação.

Se aceitar fazer parte desta pesquisa, assinale sua concordância abaixo:

( ) Concordo em participar da pesquisa, respondendo este questionário.

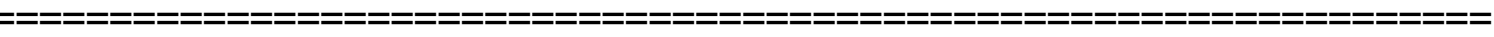

DADOS PESSOAIS

SEXO:

( ) masculino ( ) feminino

IDADE:

( ) 18 a 24 anos ( ) 25 a 34 anos ( ) 35 a 49 anos ( ) 50 a 60 anos

( ) acima de 60 anos

ESCOLARIDADE:

( ) ensino fundamental ( ) ensino médio ( ) ensino superior

( ) pós-graduação/especialização ( ) -graduação/mestrado-doutorado 
RENDA MENSAL EM REAIS(\$):

$\begin{array}{llll}\text { ( ) até } 1100 & (\text { ) } 1101 \text { a } 2200 & \text { ( ) } 2201 \text { a } 3300 & \text { ( ) 3301 a } 4400 \text { ( }\end{array}$

1. Quando faz compras, você se preocupa em saber de antemão se o fabricante/empresa atua com ações socio ambientais (responsabilidade social corporativa e com ações de sustentabilidade)?

( ) sempre ( ) algumas vezes ( ) raramente ( ) nunca

2. Tem por hábito comprar produtos e embalagens fabricados com material reciclado ou que podem ser recicláveis?

( ) sempre ( ) algumas vezes ( ) raramente ( ) nunca

3. Antes da compra, você tem o costume de verificar os rótulos e embalagens para identificar um produto ambientalmente correto?

( ) sempre ( ) algumas vezes ( ) raramente ( ) nunca

4. Nas compras, ao encontrar um produto com rótulo que informa que ele foi fabricado de maneira ambientalmente correta, você se sente motivado a comprá-lo? ( ) sempre ( ) algumas vezes ( ) raramente ( ) nunca

5. Você incentiva outros a comprar produtos de empresas que cuidam (tratam bem) do meio ambiente, de seus funcionários, da sociedade e da comunidade onde estão inseridas?

( ) sempre ( ) algumas vezes ( ) raramente ( ) nunca

6. Você tem o costume de comprar produtos de limpeza biodegradáveis?

( ) sempre ( ) algumas vezes ( ) raramente ( ) nunca

7. Você tem o costume de pagar mais por um produto que não polui o meio ambiente?

( ) sempre ( ) algumas vezes ( ) raramente ( ) nunca 
8. Você tem o costume de comprar lâmpadas e eletrodomésticos que gastam menos energia?

( ) sempre ( ) algumas vezes ( ) raramente ( ) nunca

9. Antes de jogar algo no lixo, você pensa em como poderia reutilizá-lo?

( ) sempre ( ) algumas vezes ( ) raramente ( ) nunca

10. Você tem por hábito separar o lixo que pode ser reciclado, como papel, plástico, alumínio, vidro, isopor ou metais ferrosos?

( ) sempre ( ) algumas vezes ( ) raramente ( ) nunca

11. Evita a queima de lixo doméstico (plásticos, isopor, restos orgânicos)?

( ) sempre ( ) algumas vezes ( ) raramente ( ) nunca

12. Você se preocupa em não jogar lixo na rua?

( ) sempre ( ) algumas vezes ( ) raramente ( ) nunca

13. Procura não deixar a torneira aberta ao escovar os dentes ou ao fazer a barba?

( ) sempre ( ) algumas vezes ( ) raramente ( ) nunca

14. Apaga as luzes e os aparelhos eletrônicos (computador, som, TV) quando sai do ambiente?

( ) sempre ( ) algumas vezes ( ) raramente ( ) nunca

15. Você tem o costume de orientar as pessoas sobre os cuidados com o meio ambiente?

( ) sempre ( ) algumas vezes ( ) raramente ( ) nunca 